\title{
Individualized medicine enabled by genomics in Saudi Arabia
}

\author{
Muhammad Abu-Elmagd ${ }^{1,2,3,4^{*}+}$, Mourad Assidi ${ }^{1,2 \dagger}$, Hans-Juergen Schulten ${ }^{1}$, Ashraf Dallol ${ }^{1,2}$, \\ Peter Natesan Pushparaj ${ }^{1}$, Farid Ahmed ${ }^{1}$, Stephen W Scherer ${ }^{1,5,6}$, Mohammed Al-Qahtani ${ }^{1}$ \\ From 2nd International Genomic Medicine Conference (IGMC 2013) \\ Jeddah, Kingdom of Saudi Arabia. 24-27 November 2013
}

\begin{abstract}
The biomedical research sector in Saudi Arabia has recently received special attention from the government, which is currently supporting research aimed at improving the understanding and treatment of common diseases afflicting Saudi Arabian society. To build capacity for research and training, a number of centres of excellence were established in different areas of the country. Among these, is the Centre of Excellence in Genomic Medicine Research (CEGMR) at King Abdulaziz University, Jeddah, with its internationally ranked and highly productive team performing translational research in the area of individualized medicine. Here, we present a panorama of the recent trends in different areas of biomedical research in Saudi Arabia drawing from our vision of where genomics will have maximal impact in the Kingdom of Saudi Arabia. We describe advances in a number of research areas including; congenital malformations, infertility, consanguinity and pre-implantation genetic diagnosis, cancer and genomic classifications in Saudi Arabia, epigenetic explanations of idiopathic disease, and pharmacogenomics and personalized medicine. We conclude that CEGMR will continue to play a pivotal role in advances in the field of genomics and research in this area is facing a number of challenges including generating high quality control data from Saudi population and policies for using these data need to comply with the international set up.
\end{abstract}

\section{Introduction}

Leadership of the Kingdom of Saudi Arabia, is more conscious than ever of the necessity of establishing dedicated and long-term strategies that focus on the prevention of the effects of severe genetic disorders (most often due to consanguinity) and the impact of environmental changes (e.g., Dietary changes, toxins) on the general health of the Saudi society. As outlined in Figure 1, health policy planners and biomedical research scientists have conducted landscape surveys of the challenges facing the Saudi population, and formulated strategic objectives of how to move the health care research agenda forward with defined outcomes. Many of the decisions in investment in biomedical solutions for looming medical challenges are being grounded in

\footnotetext{
* Correspondence: mabuelmagd@kau.edu.sa

+ Contributed equally

'Centre of Excellence in Genomic Medicine Research (CEGMR), King

Abdulaziz University, P.O. Box: 80216 Jeddah 21589, KSA

Full list of author information is available at the end of the article
}

establishing high-technology genomics and informaticsbased centres that exploit the unique clinical and human resources available in the Middle Eastern countries, and in particular Saudi Arabia. International expertise is also being brought in through forward looking academic consultancies with universities and through new training initiatives.

In order to apply $21^{\text {st }}$ century solutions in biomedical health research, at least three foundational genomic research initiatives are under way in the Gulf Cooperation Council (GCC), which include Kingdom of Saudi Arabia, Qatar, Oman, Bahrain, Kuwait and United Arab Emirates. These initiatives include, the catalogue of transmission genetics in Arabs (CTGA) [1] hosted by the Centre for Arab Genomic Studies in the United Arab Emirates, the Qatar Biobank Initiative [2] and the Saudi human genome program (SHGP) [3].

Established in 2003, the main purpose of the CTGA is to increase public and academic awareness for early diagnosis of genetic diseases in the Pan Arab population 


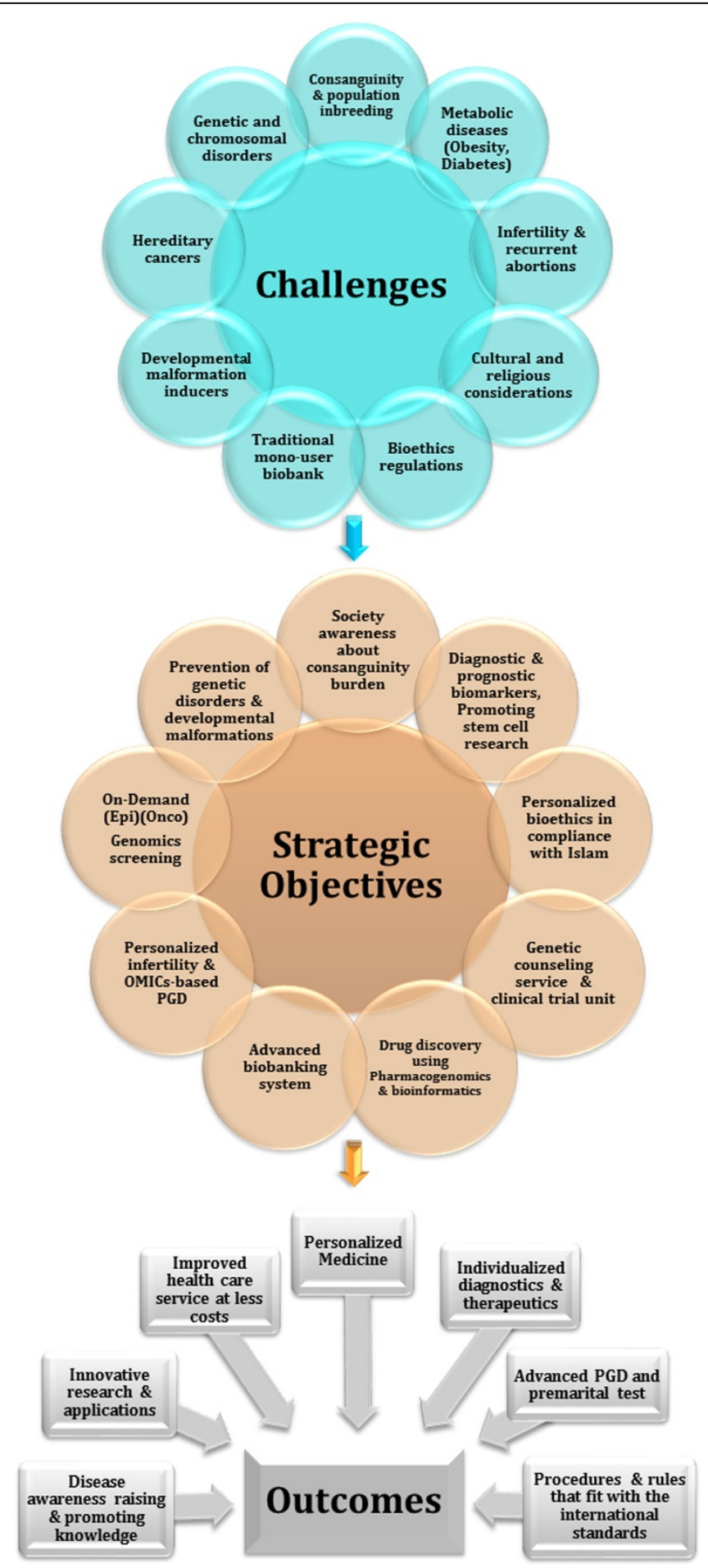

Figure 1 Challenges, objectives and expected outcomes of biomedical research in Saudi Arabia.

and to translate scientific knowledge into individualized medical treatment and management programs. As of January 2014, the CTGA online database curates over 1,000 disease phenotypes with a focus on the epidemiology in the Arab world, and it also maintains a record of nearly 250 associated disease loci. Many of the disease phenotypes studied are either more frequent (such as G6PD deficiency) or are regionally endemic, restricted to certain 
tribal communities or even unique to consanguine families. Consanguinity, which is a main feature of the traditional Arabic culture (see below), leads to an increase of homozygosity for autosomal recessive genetic diseases which, from the perspective of research, can serve as an important repository for phenotype-genotype association studies [4]. The Qatar BioBank was initiated in 2010 aiming to take biosamples from Qatari population into repository to investigate diseases common to the domestic population [2]. Its ambitious goal is to serve as a driver for biomedical research inside and outside of Qatar. The SHGP intends to sequence the exomes and/or genomes of 100,000 Saudis within a period of five years taking advantage of the feasibility of next generation sequencing (NGS) [3]. In one of the large investments, NGS utilizing the Ion Proton technology (LifeTechnologies) has been allocated to the core facility of the SHGP in the capital Riyadh in addition to 15 planned satellite facilities across the Kingdom covering a substantial part of the 30 million nation's populated areas. The satellites are established as collaborating institutions with self-adopted timelines and projects, which are led by on-site researchers independently from the SHGP headquarter.

Using the new genomic data, the SHGP is aiming to investigate a number of diseases, which are common or endemic in the country and have a strong genetic component such as diabetes, deafness, cardiovascular disease, neurodegeneration, cancer and inherited and Mendelian disorders (discussed below). Translational research aspects of this project include genetic counselling and in some instances further genetic testing of families where the underlying genetic mutations have been identified. For example, a number of genetic counselling services for inherited disorders like the pre-marital screening and genetic counselling program in Saudi Arabia for hemoglobinopathies and viral infections have been implemented [5]. Developing applications in pharmacogenomics research and personalized medicine are prospective objectives that may also arise from the SHGP. In addition, the aggregate genetic information offers the opportunity to perform genome wide association studies (GWAS) in a new dimensional scale. Such studies may shed light upon a number of polymorphic traits that are associated with certain diseases and are suspected to add to their penetrance which may gain special importance for endemic conditions like body mass index and obesity [6], or for acute diseases like cancer [7].

Our review is divided into five themes that we believe are most relevant for genomic technologies to have impact in Saudi Arabia. We ordered the themes based on our interpretation of the challenges unique to Saudi Arabia and the Middle East (Fig. 1). We believe the investment in research will have significant impact on our own health care systems and the lessons learned will also have an impact in other regions of the world, in particular as population migration expands and genetics becomes fully integrated into medical management for individuals and their family members [8]. Our vantage point is from working within the Centre of Excellence in Genomic Medicine Research (CEGMR), King Abdulaziz University (KAU), Jeddah, Kingdom of Saudi Arabia (KSA). This dynamic organization is aiming to develop and apply the best practices in genomic medicine driven by world-class research programs (Fig. 2) to further the health of citizens of Saudi Arabia and the world.

\section{Congenital malformations in Saudi Arabia}

Congenital malformations are identified as physical irreversible alterations induced during embryo formation that can be grouped into five categories: (1) single-gene anomalies, (2) chromosomal abnormalities, (3) maternal illness conditions during early pregnancy, (4) environmental and genetic inducers (e.g., teratogens), and (5) unknown causes, which account for $\sim 50 \%$ of congenital malformations [9].

In Saudi Arabia, a number of studies were carried out to screen for congenital abnormalities in different regions of the kingdom (Fig. 3). In the Western province of Saudi Arabia, a high prevalence of major congenital abnormalities including cardiovascular, musculoskeletal, urinary and central nervous system (CNS) was reported [10]. Interestingly, this study showed that at least $38 \%$ of the parents of babies with congenital malformations were consanguineous. More supporting evidence from large multicentre studies conducted across Riyadh and the Eastern region revealed that first cousin marriage have a direct link with a number of congenital heart defects (CHD) [11-14]. Severe $\mathrm{CHD}$ were also reported in large studies in Al-Qassim (central region) with authors attributing the severity to the high rate of consanguinity $[15,16]$. These findings are not surprising since Saudi Arabia has the highest consanguinity among all middle eastern countries [17]. Based on Saudi Arabian regional distribution, South-Western and Northern provinces have the highest prevalence of CHD (Fig. 3)[18]. In Najran in South province, a significant high prevalence of hypothyroidism and hyperthyroidism associated with $\mathrm{CHD}$ were reported and attributed to high rate of consanguinity [19-21]. In Asir region in the South province, a high prevalence of a number of congenital malformations was detected in newly born babies and found to be linked to high consanguinity. Among these are gastrointestinal tract anomalies [22], CNS defects [23,24] and cardiovascular system defects [25]. All previous studies used hospital database analysis, however, the first community based study to measure the prevalence of $\mathrm{CHD}$ was carried out by Alqurashi, et al., 2007 [26]. This study showed that the central region had the highest CHD prevalence of 27 per 10,000 and the north-western was the least affected region with prevalence of 9 per 10000 [26]. 


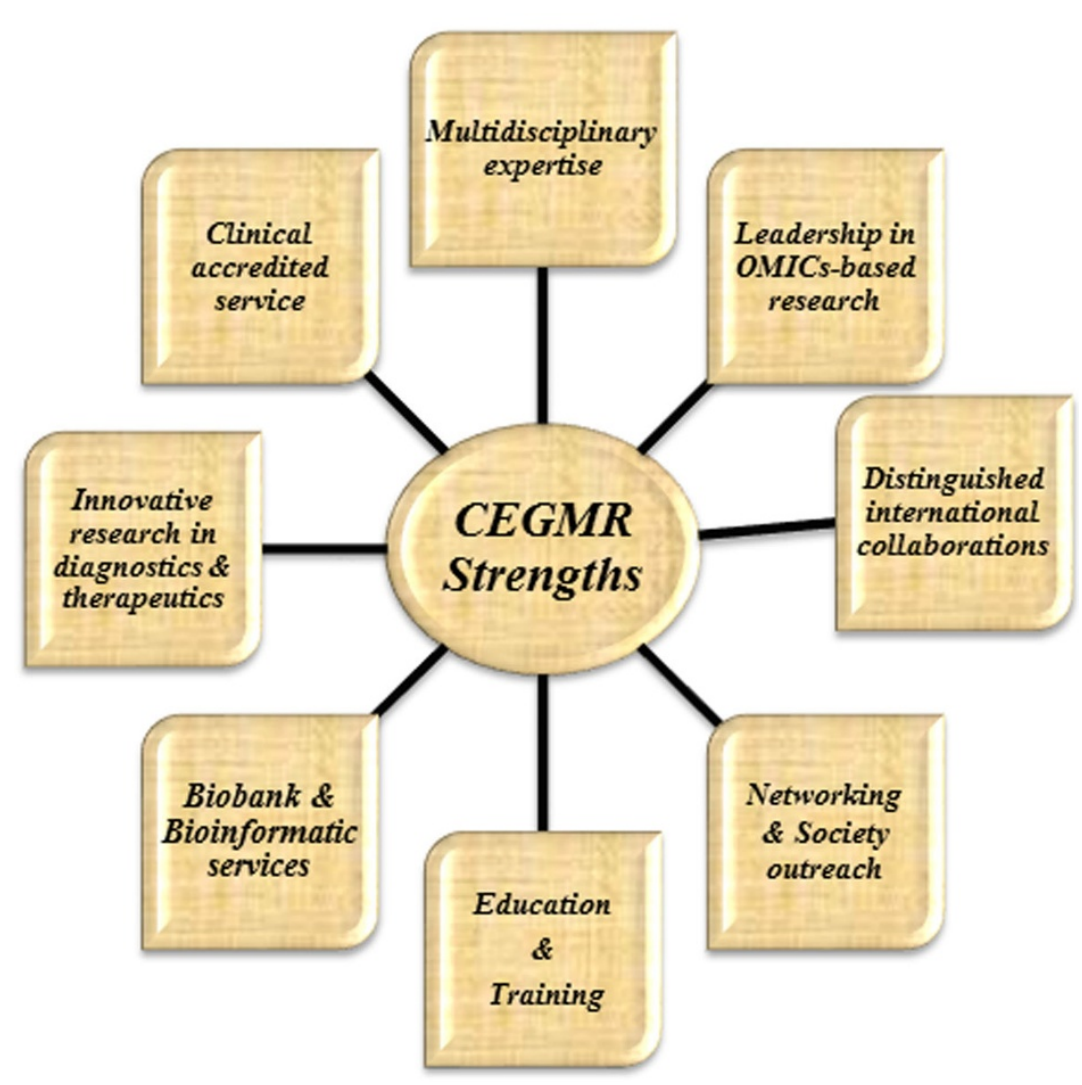

Figure 2 Centre of Excellence in Genomic Medicine Research (CEGMR) Multi-disciplinary platforms in biomedical research.

\section{Congenital Heart Defects CHD [18, 26] \\ Cardiovascular, musculoskeletal, Urinary, Gastrointestinal, Central nervous system and Cleft palate anomalies [10, 32]}

Congenital heart defects/Hypo- or Hyperthyroidism, Gastrointestinal tract anomalies, Central nervous system defects, Microcephaly, Seizures and Intracranial calcification, Cardiovascular system defects $[19-25,35,36]$

Congenital heart defects CHD, Neural tube defects $[10-16,26-28]$

\section{Congenital Heart Defects CHD [11-14, 18]}

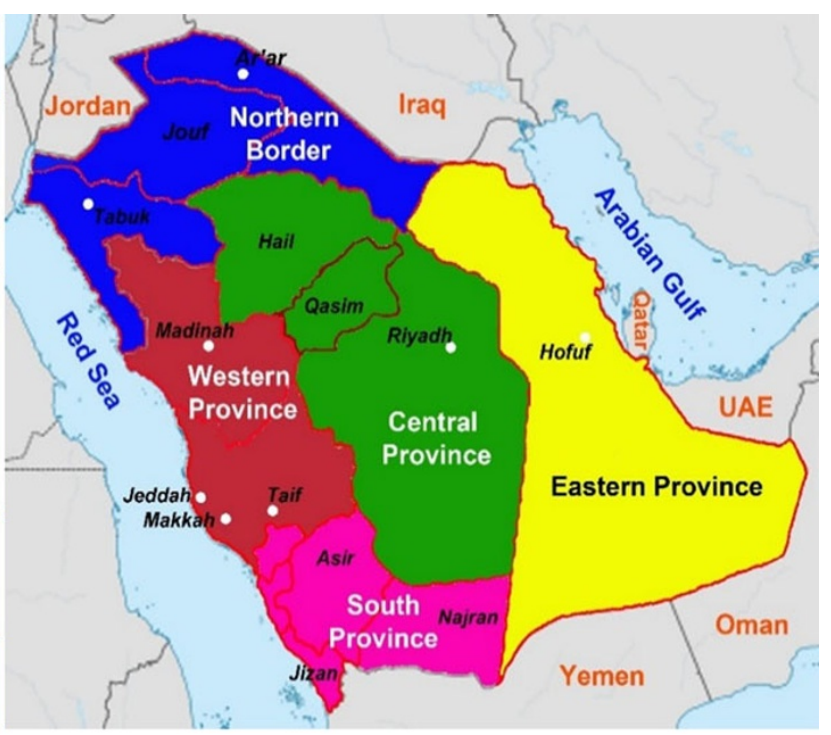

Figure 3 Regional prevalence of cardiac heart defects $(\mathrm{CDH})$ in the Kingdom of Saudi Arabia. 
A wide range of the CNS malformations including neural tube defects have been detected in different regions of Saudi Arabia with consanguinity appearing to be a major risk factor $[23,24,27,28]$. The mountainous geography of Saudi Arabia may also contribute to the high rate of congenital malformations since high altitude has been reported in other regions worldwide as a cause of congenital anomalies [29-31]. In Al-Taif city, known as a very high-altitude area, an increase in cardiovascular, urogenital, musculoskeletal, gastrointestinal, and cleft palate anomalies in addition to chromosomal abnormalities were reported [32].

Due to strong economic stability, obesity in Gulf countries in general and in Saudi Arabia and Kuwait in particular has become a high risk factor and a serious problem that reflects negatively on the these societies [6]. According to the Saudi Arabian national nutrition survey issued in 2007, the prevalence of obesity among women is $23.6 \%$ compared to $14.2 \%$ in men [33]. It has been reported that a mother's body mass index of more than 30 is a predictor of a number of congenital malformations including cardiac, nervous system, facial and genitourinary tract defects [34]. Environmental factors and metabolic disorders are believed to induce congenital infections with toxoplasmosis, and cytomegalovirus that in turn result in inducing a number of congenital malformations including; microcephaly, seizures and intracranial calcification $[35,36]$.

Different genomic research approaches to elucidate the causes of congenital anomalies in Saudi Arabia have recently begun to gain more attention. For example, a multi-level technology approach was used to unravel the molecular network that lead to cryptorchidism [37]. Comparative genomic hybridization ( $\mathrm{CGH}$ ) was also used to analyse chromosome microdeletions that caused upper limbs disabilities [38], and exome sequencing led to the identification of the ADAMTS18 gene to be involved in eye development [29].

Despite a recommendation to launch a national screening program for congenital anomalies in 1997 [20], there remains a real need for a primary national prevention program. We believe this type of program should be congruent with an awareness program of the genetic and epigenetic causes of the birth defects in Saudi Arabia. There is support for the implementation of an extensive pre-marital and pre-implantation screening program, in addition to establishing a national database for congenital anomalies, and by offering genetic counselling when birth defects occur $[39,40]$. Recently, King Faisal Specialist Hospital \& Research Centre (KFSH \& RC) in Riyadh launched a technical database core facility that aims to maintain database registries of a number of diseases and congenital defects in order to facilitate clinical and research domains in Saudi Arabia
(http://rc.kfshrc.edu.sa/besc/sections/tdbcf/OurProjects. html). Among these registries are; new-born screening and biochemical genetics (http://nlnbs.kfshrc.edu.sa), cleft lip/palate and craniofacial anomalies (http://rc. kfshrc.edu.sa/bssc/clcpr_new/buttons/New_Site.htm), congenital heart defects (http://rc.kfshrc.edu.sa/ chd_program/) and neural tube defects (http://rc.kfshrc. edu.sa/ntd/). Establishing similar regional initiatives connected to a central database facility would reveal the most accurate data on congenital malformations in Saudi Arabia.

At CEGMR, a number of research initiatives are already in place to screen and investigate the causes of congenital malformations in Saudi Arabia. Among these initiatives are KACST's recently funded projects to apply microarray based $\mathrm{CGH}$ approach to unravel genome defects in the congenital heart diseases and another to screen and diagnose the developmental delay as well as other congenital malformations. In addition, CEGMR established a collaboration with the Environmental Sciences Department at KAU to analyse changes in gene expression profiling using array CGH, RNA-Seq and whole exome sequencing during early embryonic development that could be induced by air particulate pollution and pesticides.

\section{Infertility and pre-implantation genetic diagnosis (PGD)} Infertility is a condition manifested by the biological incapacity of a couple to achieve a clinical pregnancy after at least one year of regular unprotected sexual intercourse [41]. The prevalence of this disease continues to rise and affects about 1 out of 6 couples in Saudi Arabia and worldwide $[42,43]$. Such infertility rates vary largely among countries and patient age [44]. The most common factors that could explain this severe decline in fertility are reproductive aging through the postponement of marriages, lifestyle, nutrition, the quality of health care services, and decrease in the child-seeking behaviour [45-47]. These factors are mainly due to the maternal age and to a lesser extent the paternal factors that could correlate with increased rates of gametes' chromosome cohesion and therefore higher aneuploidy and chromosomal abnormalities in blastocysts [48-50].

There is an increase in the number of couples seeking infertility treatment services in assisted reproductive technologies (ART) clinics to help them to procreate. Despite valuable ART advantages, a remaining challenge is to increase qualitatively and quantitatively the in vitro fertilization (IVF) outcomes and reduce health care costs for both the mother and the offspring [51,52]. The gametes' (spermatozoa and oocyte) quality has been recognized as the major limiting step and is therefore the target of numerous studies to improve their selection procedure [53-56], in order to make the elective single 
embryo transfer (eSET) procedure more effective [57,58]. Chromosomal and some genetic mutations have been reported to underlie many of the challenges for obtaining successful embryo implantation and subsequent delivery of healthy babies [59-61].

In addition to the infertility challenges, Saudi society in particular is characterized as mentioned above by an extremely high-level of consanguinity. In fact, large proportions of marriages are still driven by ethnic or tribal considerations. The rate of consanguineous marriages is about $58 \%$ amongst them $60 \%$ were between first-degree cousins [12,17], which represents one of the highest in the Middle East and worldwide. In addition to the increase of the frequency of inherited recessive disorders, these consanguineous marriages have direct effects on some reproductive health parameters such as infertility rates, recurrent abortions, congenital disorders and neonatal death (Table 1) [4]. It should be highlighted that these genetic and chromosomal disorders' rates are variable among regions inside Saudi Arabia. Additionally, these rates are exceptionally high in Saudi Arabia and Middle East in general compared to other regions in the world due to the burden of consanguinity and population inbreeding.

Given the challenges of high rates of consanguinity and disease in the Middle East and in Saudi Arabia, the Saudi ministry of health (MOH) decided in 2004 to make the premarital testing compulsory [5,62]. Such premarital examination includes mainly the basic blood tests, the hemoglobinopathies screening (Thalassemia \& Sickle Cell Anaemia) and virology assays (Hepatitis B and C; AIDS). Despite these important measurements, PGD is still restricted to only few IVF clinics and it is the opinion of the authors that the level of awareness about infertility problems and genetic diseases needs to be given more attention especially in regions with high consanguinity as well as in rural and tribal areas. Investment in training and staffing in genetic counselling will also then be required.

The CEGMR aims to play a leading role in PGD by building translational research capacity. CEGMR is currently working in collaboration with KACST Centre of Innovation for Personalized Medicine (CIPM), Jeddah at KAU; the latter is being involved in delivering service through PGD screening for the larger Saudi population. CEGMR is currently developing new infertility screening methods using a specific panel of biomarkers with the primary aim being to reduce the comparatively high recurrence of abortions. For examples, new advances in technology have allowed the transfer of two embryos to the eSET preventing multiple pregnancies, which can disadvantage both the mother and the baby [63]. Similarly, a new project was recently initiated to establish an advanced premarital screening (APS) using state-of-the-art approaches with higher coverage (number of diseases) and accuracy. Once validated, such APS package will be presented to the $\mathrm{MOH}$ for consideration as an improvement of the existing test using advanced high throughput technologies.

Together, fertility and PGD screening programs as well as the APS package are excellent tools that are on line with the latest advances in the reproductive and developmental medicine field worldwide and are expected to significantly enhance the efficiency of both infertility diagnosis and treatment [64-66]. They will also facilitate detection and prevention of the transfer of most of the inherited disorders to the upcoming generations.

\section{Cancer and genomic classifications in Saudi Arabia}

All six GCC countries curate national cancer registries that provide statistics measures to the Gulf centre for cancer registration [67-70]. Remarkably, the national cancer registers of Bahrain, Kuwait, Oman, and Qatar are listed in a high incidence data quality category as assessed by the international agency for research on cancer (IARC) [71]. In comparison with USA, cancer data indicates a lower incidence rate for cancer in the Gulf region (Fig. 4); yet, a certain deviation of the frequency of the most common cancer types is observed [72]. For example, thyroid and liver cancer, as well as leukaemia and non-Hodgkin`s lymphoma (NHL) are relatively more common than in the USA (all races) $[68,72]$. Thyroid cancer is the second most frequent cancer in young women in the majority of the GCC countries [73,74]. Contrarily, prostate cancer is less frequent in the Gulf region, especially in Saudi Arabia [75]. In most common cancer types including thyroid and breast cancer, patients are several years younger at first diagnosis compared to Western countries $[67,72,76,77]$. Molecular genetics studies from the Gulf region have demonstrated that hereditary components like single nucleotide polymorphisms (SNPs) confer risk for breast [78] and thyroid cancer $[79,80]$. More specifically for the p53 codon, 72 polymorphism showed an association with early onset of breast cancer in Saudi women [81].

A high prevalence of childhood cancer in relation to adulthood cancer is observed in the GCC region. This discrepancy is in first instance attributed to the young population structure of the region $[67,82]$. Similar to Western countries, leukaemia and lymphomas including both Hodgkin's lymphoma and NHL are among the most frequent paediatric cancers (Fig. 5). To provide specialized paediatric cancer care, the King Fahd National Centre for Children's Cancer and Research, hosted by KFSH \& RC, was established in 1997 in the Saudi capital Riyadh. The paediatric clinic, the largest in the region, performs approximately 70 stem cell transplantations per annum. One of the research areas of both institutions is focusing on the molecular genetics of diffuse B-cell lymphomas, 
Table 1 An overview of the main genetic and chromosomal disorder in Saudi Arabia and their relationship with consanguinity. $(++)$ : High correlation; (+): Positive correlation; ND: Not Determined.

\begin{tabular}{|c|c|c|c|c|}
\hline Type & Disease & Disease prevalence* $(\%)$ & Consanguinity & References \\
\hline \multirow[t]{2}{*}{ Chromosomal } & Down syndrome & 1.8 & ND & [172] \\
\hline & Congenital Malformations or birth defects & $2-3$ & ++ & {$[12,13,173]$} \\
\hline \multirow[t]{7}{*}{ Polygenic and/or multifactorial } & Congenital heart disease (CHD) & $5.4-10.7$ & + & {$[15,174,175]$} \\
\hline & Cystic fibrosis & 0.24 & ++ & [176] \\
\hline & Duchene muscular dystrophy (DMD) & 0.025 & + & [177] \\
\hline & Hereditary Recessive deafness & 130 & ++ & [178-180] \\
\hline & Hereditary blindness \& visual impairment & 90 & ++ & {$[181,182]$} \\
\hline & Diabetes mellitus & 110 to 237 & ND & {$[183,184]$} \\
\hline & Thalassemia & 0.5 to 2.6 & ++ & [185-188] \\
\hline \multirow[t]{2}{*}{ Monogenic } & Sickle Cell Disease (SCD) & 9 to 14.5 & ++ & {$[185,187,189-192]$} \\
\hline & G6PD deficiency & 7.7 to 20 & ++ & {$[12,193,194]$} \\
\hline
\end{tabular}

${ }^{*}$ Rates from national and/or regional studies done in Saudi Arabia

which are the most common subtype of extranodal NHL and occur with a comparably high prevalence in the Gulf region [83-85]. Notable findings include detection of clinically relevant biomarkers such as SKP2, XAIP, FOXM1, and $M E T$ in diffuse large B-cell lymphomas and detection of molecular mechanisms for $N F K B$ in activated B-cell lymphomas [83,86-89]. For acute lymphoblastic leukaemia (ALL), a Saudi retrospective multicentre study revealed clinical characteristics similar to those found in developed countries; however, the authors noticed that standardization of patients ' care has to be improved [82]. Interestingly, an epidemiological survey in the Detroit area of USA revealed a higher incidence of leukaemia and bladder cancer in US-born males of Arab origin compared to nonHispanic whites [90] indicating a possible involvement of inherited susceptibility factors in these malignancy types, as shown for other diseases like thyroid and breast cancer [79-81,91]. These findings emphasize the genetic heterogeneity of major cancer types, in which NGS may become the tool for personalized medicine intervention.

\section{Epigenetic explanations of idiopathic disease}

A marked feature of cancer in the Kingdom of Saudi Arabia is the relatively young age of onset. The most common cancer type in Saudi Arabia is breast cancer comprising more than $16 \%$ of the cases seen at the largest oncology referral centre in the Kingdom, KFSH \& RC [92]. Most of the affected females are below 50 years of age [92], which differs from Western countries where the age of onset is later [93]. Colon cancer is the most cancer type affecting Saudi males and here too the age of onset (40-65 years) [92] is less than seen in the west [93].

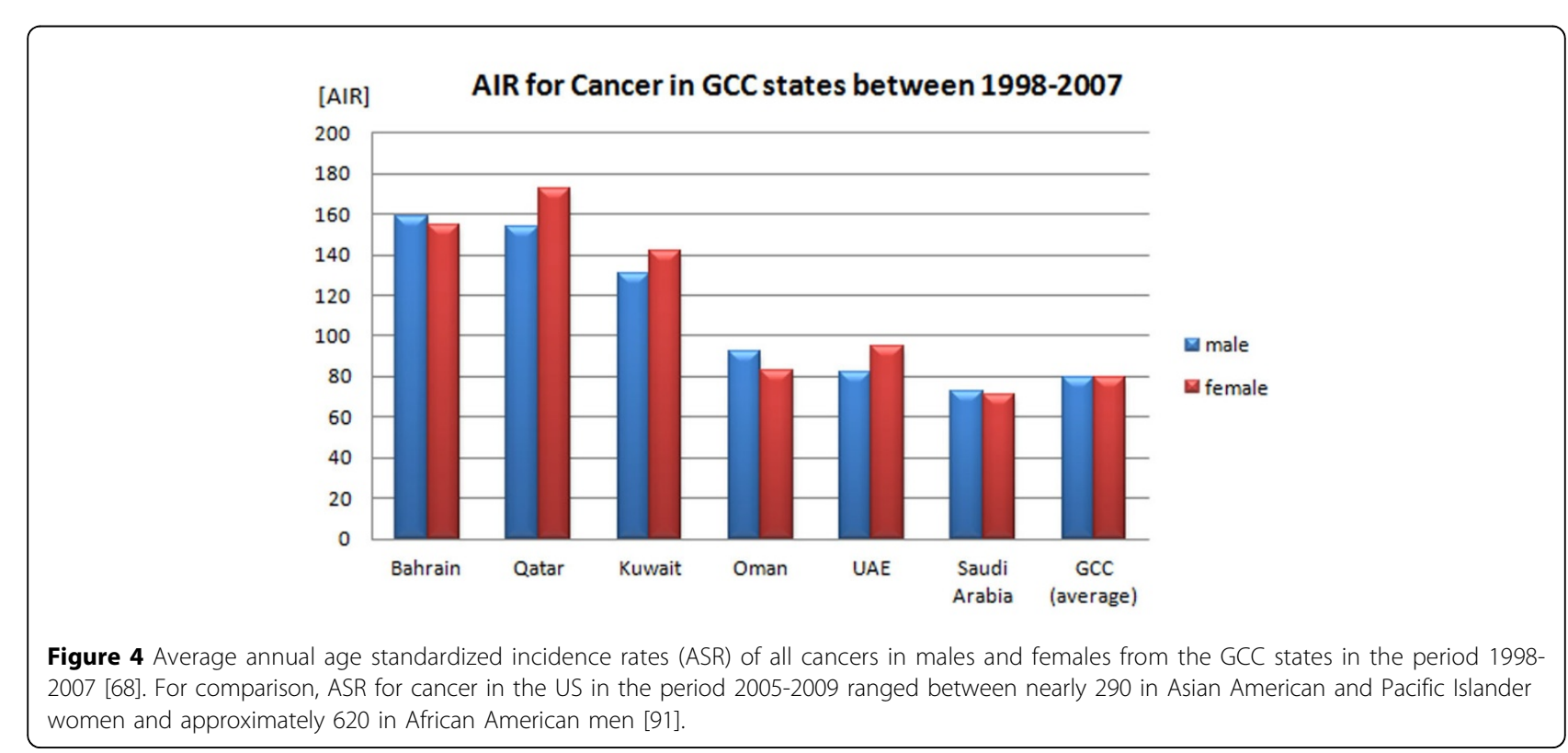




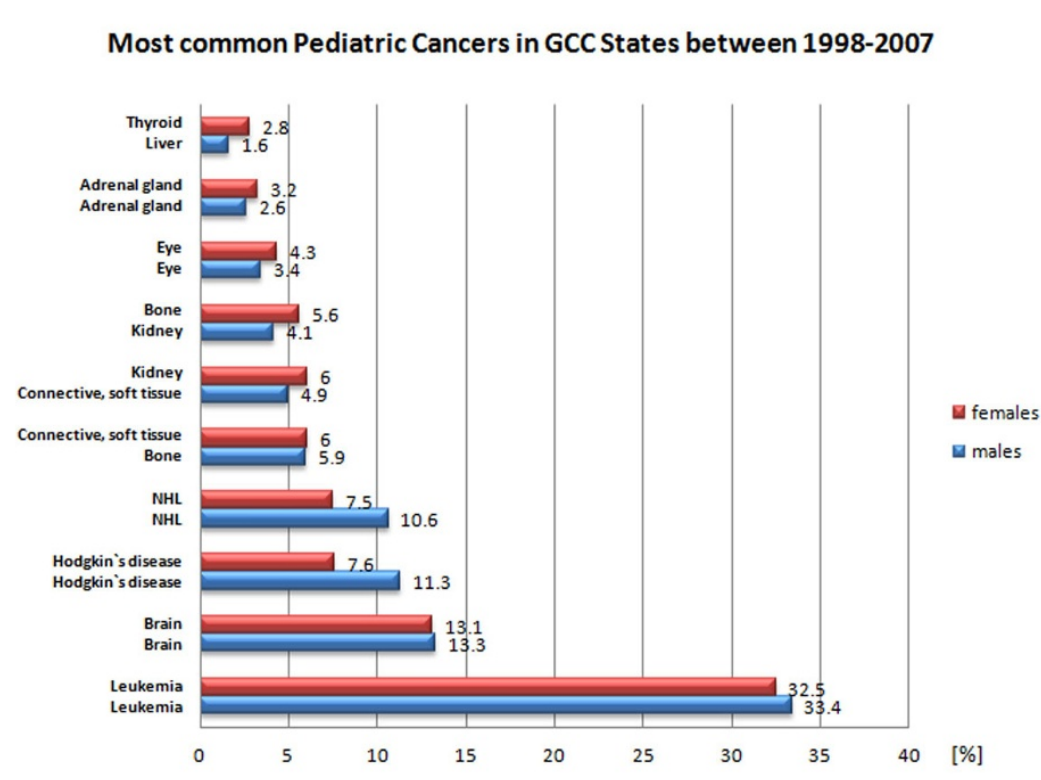

Figure 5 Most common cancer types in the period 1998-2007 for children between 0-14 years from the GCC states [68]. Leukaemia, brain cancer, Hodgkin's diseases, and NHL were the most common malignancies in both genders.

The reason for such age discrepancy is not entirely known. However, factors such as the early age of menarche $(<12$ years) and the use of exogenous progesterone and oestrogens could be suspected in the case of breast cancer [94]. The relatively young age of onset in this population could be explained by the interplay between common genetic susceptibility background substantiated by increased consanguinity and epigenetic aberrations. These factors are thought to be caused by shifts in life style being experienced in Saudi Arabia and in the Middle East in general in the past few decades. Similar life-style shifts are also seen in emerging economies such as India. Similar to Saudi Arabia, there is an increasing number of younger patients diagnosed with cancer every year in India [95]. The presence of a common genetic susceptibility factor(s) amongst Saudis is unknown. Interestingly, no significant associations of BRCA1 and BRCA2 mutations or SNP have been found in Saudi breast cancer cohorts [96,97]. However, there is an ongoing study to elucidate this further at CEGMR using high throughput technologies including Ion Torrent whole genome sequencing. In addition, our exome sequencing efforts of familial breast cancer cases have yet to reveal a common gene or mutation in the samples so far analysed [98]. Interestingly, every family sequenced thus far has a different underlying putative defective gene (s) precluding our ability to provide supporting evidence for the hypothesis that suggests the presence of a consanguinity-driven common genetic haplotype associated with increased susceptibility to breast cancer [98]. A more defined role for a "cancer susceptibility genome" will be determined following the conclusion of the SHGP project [99].

Epigenetics could therefore play a major role in the shift towards a younger age of onset. Life-style changes such as sleep and shift work patterns, diet and exercise can affect the genome in several ways and need to be considered. The circadian rhythm, mediated through an intricate network of transcriptional and post-translational mediators is necessary for maintaining a healthy homeostasis [100-102]. When the circadian rhythm is disrupted through sleep deprivation, global changes in gene expression can occur altering cellular behaviour. Methylation is a key mechanism for altering gene expression in response to sleep deprivation, such as what happens to the brain function [103]. The pleiotropic melatonin is the main sensor for light and it has cancer-protective effects through several mechanisms, including regulating estrogen pathway [104]. Interestingly, we have identified frequent hypermethylation of the melatonin receptor, $M T N R 1 B$, in a fraction of our cohort of breast cancer cases (35\%) with significant association with histological grade I [105]. Such a result is intriguing and could implicate the epigenetic deregulation of key components of the circadian clock, which in turn, could potentiate cancer at an early age $[100,101]$.

Sleep deprivation is not the only suspect behind the age shift observed. Aberrant metabolism is also likely to play a role. The incidence rates of the metabolic syndrome (obesity, high blood pressure, elevated fasting glucose 
levels, elevated cholesterol levels) in Saudi Arabia are reported to be among the highest in the world [106]. There is also emerging evidence of metabolic syndromes contributing to the increasing rates and age shift of cancer in Saudi Arabia. Our genome-wide methylation analysis of breast cancer has identified a role for the KLOTHOFGF19-FGF23-FGFR4 signaling axis. FGF19 expression is elevated and is associated with a significantly shorter life expectancy of breast cancer patients of Saudi and Libyan descent [107]. The upregulation of FGF19 expression is coupled with high FGF23 and FGFR4 expression and frequent methylation of KLOTHO in the same cohort (Unpublished data). While a role for FGFR4 has been previously shown $[108,109]$, implicating the metabolic hormones FGF19, FGF23 and KLOTHO in cancer is equally intriguing; the emerging question being if dysregulation of these genes may be a direct cause of carcinogenesis or more generally a symptom of metabolic health, which in itself predisposes to cancer at a significantly younger age? More work is warranted to shed light on the role of this metabolic axis in cancer because of its potential as an actionable target for treatment $[110,111]$.

Other genes are inactivated by promoter hypermethylation. In colorectal cancer from Saudi Arabia, the methylation of the polycomb gene targets in the absence of $\mathrm{CpG}$ island methylator phenotype (CIMP) is a predictor of favourable prognosis [112]. Interestingly, we have identified a group of older patients with no detectable methylation in the genes analysed and yet displayed aggressive tumours that led to a significantly lower disease-specific survival rates [112]. The most frequent methylation event detected in breast cancer from Saudi cases is at the RASSF1A promoter, an event that is a potential predictor of poor prognosis [113]. However, the methylation frequency of other genes analysed in that study was lower than reported elsewhere, especially in the case of Estrogen Receptor-1 (ESR1) and Cadherin-1 (CDH1) methylation [113]. This could be attributed to the relatively early age of onset for the patients analysed, or to the presence of regional and ethnic-specific differences in gene regulation in breast cancer. BRCA1 methylation in blood from breast cancer patients could provide a potential mechanism for cancer susceptibility in the Saudi population and offer a promising tool for the detection of cancer predisposition [114]. Amplification of TNRC9, a common event in breast cancer from the MENA region, can directly result in the epigenetic silencing of BRCA1 expression [115]. Incidentally, SNPs in the TNRC9 locus have been shown to be significantly associated with breast cancer [116].

Other epigenetic lesions underlying cancer in Saudi Arabia could exist. Differential expression of miRNAs including hsa-mir-146a2, hsa-mir-196a2 and hsa-mir-499 are detected in peripheral blood of breast cancer patients [117]. Furthermore, polymorphisms identified in those
miRNAs have been found to be significantly associated with breast cancer susceptibility [117]. A similar effect is observed in risk modification for prostate cancer in northern Indian populations [118]. Polymorphisms in hsa-mir-196a has been shown to be associated with increased risk for nasopharyngeal carcinoma in Chinese patients [119], and with increased risk for non-small cell lung carcinoma in the Korean population [120]. Conversely, these genetic variants do not seem to influence breast cancer risk or age of onset in German or Italian populations [121].

\section{Pharmacogenomics and personalized medicine}

Pharmacogenomics (PGx) is the study of the role of genetic polymorphisms in drug response [122,123]. PGx is a rapidly evolving field in particular due to the rapid advances in genotyping platforms and NGS technologies to scan the genome at increasing levels of resolution [124]. The interface of PGx and complex diseases including various types of cancers, understanding and managing serious adverse drug reactions (SADRs), and public health pharmacogenetics, are the major areas of investigation at CEGMR and elsewhere [124,125].

The potential opportunities emerging from PGx include, but not limited to, the prediction of personalized response to drugs, tailor-made prescriptions, reducing adverse drug reactions (ADRs), increasing the efficacy and reducing the toxicity of drugs, developing more robust and safer vaccines, monitoring and screening of specific diseases, as well as advancing research and development of novel drugs [122]. Pharmacogenetics (PGt) is the study of single genes that have significant influence on clinically actionable drugs [126].

In the past two decades, several drugs were primarily withdrawn from the USA market due to ADRs $[125,127,128]$. The ADRs are broadly categorized into Type A and B reactions [127]. Type A reactions are predictable, dose-dependent and constitute about $80 \%$ of ADRs [125,127]. The hypotension with anti-hypertensive treatment and incidences of bleeding in patients treated with Warfarin are some of the examples of Type A ADRs [125,127]. However, Type B reactions are termed as "idiosyncratic" or random ADRs observed mostly in genetically susceptible individuals [127]. Moreover, Type $B$ reactions may potentially lead to SADRs that require either temporary or prolonged hospitalization and in some instances permanent disability or are even fatal $[125,129]$. Deciphering the genetic variations in populations [130], associated with Type B reactions using PGx strategies, could markedly reduce the healthcare budgets, promote drug discovery and the development of reliable and safer drugs [125,129].

The Cytochrome P450 (CYP450) super-family consists of functionally diverse groups of drug detoxifying 
enzymes encoded by 57 genes and 5 pseudo genes, identified thus far, in the human genome [131,132]. The CYP450 enzymes are chiefly expressed in liver and facilitate the metabolism of drugs, xenobiotics, toxic pollutants, steroids, vitamin D, cholesterol metabolism and bile synthesis, retinoic acid, arachidonic acid and eicosanoids $[132,133]$ by conjugating with functional groups and eventually removal from the body [132,134,135]. Members of the CYP450 super-family like CYP1, CYP2, and CYP3 are essential for the phase I metabolism of about $90 \%$ of all clinically applicable drugs [134-136]. The personalized variations in the expression of chief detoxifying CYP450 enzyme systems in humans, such as CYP1A2, CYP2C, CYP2D6, CYP2E1, CYP3A4 and $C Y P 3 A 5$, can influence the metabolism of a clinically relevant drug and the ADRs associated with its standard doses $[124,135,136]$. An array of factors such as the genetic polymorphisms, poor diet, endocrine dysregulation, epigenetic changes, acute and chronic liver diseases can critically influence the personalized variation in the expression of CYP450 system [135,137]. Besides, the CYP450 clinical phenotypes are classified based on individuals' ability to metabolize a particular drug as ultrarapid metabolizers (UMs), Extensive Metabolizers (EMs), Intermediate Metabolizers (IMs) and poor metabolizers (PMs) [138,139]. The PMs have two non-functional alleles that decrease the expression of a particular CYP450 enzyme [136]; IMs have one functional allele and one heterozygous null allele for a CYP450 enzyme [136]. EMs have two functional homozygous alleles and may require higher concentrations of a therapeutic drug compared with IMs and PMs [136]. UMs have two or more copies of a functional CYP450 gene and metabolize the drug substrates rapidly and always require higher concentrations of drugs to achieve good therapeutic outcomes [136].

Genetic polymorphisms of CYP450 superfamily of genes greatly influence the efficacy, safety and the clinical outcome of a drug treatment [136]. CYP2D6 is one of most important CYP450 enzyme required for the metabolism of more than $30 \%$ of therapeutically relevant drugs, including antidepressants and antipsychotics $[138,139]$. It is polymorphically expressed, and found to be absent in 1-2\% of Asians, $6-10 \%$ of Caucasians [139] and are classified as PMs [138,139]. Over 25\% of Ethiopians and $2 \%$ of Caucasians are classified as CYP2D6 UMs [138,140]. In general, PMs of drugs have an increased risk of developing ADRs when compared to UMs and EMs. For example, codeine, a pro-drug, is converted to morphine by CYP2D6 enzyme to exert its analgesic properties [140]. Therefore, the efficacy of codeine was significantly reduced in individuals with CYP2D6 PMs [140]. On the other hand, the efficacy of codeine was markedly increased in CYP2D6 IMs and
CYP2D6 UMs leading to drug toxicity in some individuals [140].

CYP2C subfamily of enzymes metabolizes about $20 \%$ of clinically relevant drugs including non-steroidal antiinflammatory drugs (NSAIDs), oral anticoagulants and oral anti-diabetic agents such as tolbutamide, glibenclamide, glimepiride and glipizide [141-143]. To date, more than 57 alleles of CYP2C9 have been reported [144] amongst which CYP2C9*2 and CYP2C9*3 alleles are the most prevalent in Caucasian as well as Asian populations and individuals carrying these polymorphisms exhibit reduced CYP2C9 activity [141]. An association was established between reduced expression of CYP2C9 and higher risk of bleeding episodes and upper-gastrointestinal (GI) bleeding in Warfarin-treated patients [136,145]. The alleles of CYP2C9 namely, CYP2C9*2 and CYP2C9*3 are responsible for reduced CYP2C9 enzyme activity leading to increased anti-coagulation [136]. These patients should be administered with lower dose of Warfarin to attain effective anti-coagulation, and diminish the possibility of bleeding episodes $[136,145,146]$.

In Oman, the frequencies for CYP2C9*2 and CYP2C9*3 alleles were shown as $7.4 \%$ and $2.9 \%$ respectively $[147,148]$. In Egypt, the allelic frequencies of CYP2C9*2 and CYP2C9*3 alleles were estimated as $12 \%$ and $6 \%$ respectively [149]. In Lebanon, the allele frequencies for these two alleles were found to be $11.2 \%$ and $9.6 \%$, respectively $[148,150]$. The frequencies of CYP2C9*2 and CYP2C9*3 alleles among Saudis in Al-Ahsa were about $13.4 \%$ and $2.3 \%$, respectively [148]. In Riyadh, the frequencies for CYP2C9*2 and CYP2C9*3 alleles were reported to be $11.7 \%$ and $9.7 \%$ respectively [143]. The analysis of common genetic variants of the CYP2C9 subfamily in type 2 Diabetes mellitus (T2DM) patients in Jeddah showed that the allele frequencies of CYP2C9*2 and CYP2C9*3 were $25 \%$ and $9.3 \%$, respectively (personal communication, Nehad Abdulqader Shaer and Ashraf Dallol). It was recently shown that the incidence of CYP2C9 polymorphisms in Saudi population was comparable to Caucasians; however, it was higher than Africans and Asians [151]. Saudi patients with CYP2C9*2 and CYP2C*3 alleles had more adverse bleeding episodes and require $40 \%$ less Warfarin dose to cause effective anti-coagulation (Fig. 6) [151].

In December 2004, the United States food and drug administration (FDA) approved the drug metabolizing enzyme (DME) genotyping system from Roche named as AmpliChip ${ }^{\mathrm{TM}}$ CYP450 array [152]. The AmpliChip P450 array is used in Affymetrix GeneChip microarray instrumentation system to identify a patient's CYP2D6 and CYP2C19 genotypes from genomic DNA isolated from whole blood sample [152]. Based on the CYP450 genetic test results, clinical evaluation and other lab tests as a reference, the clinician designs personalized treatment 


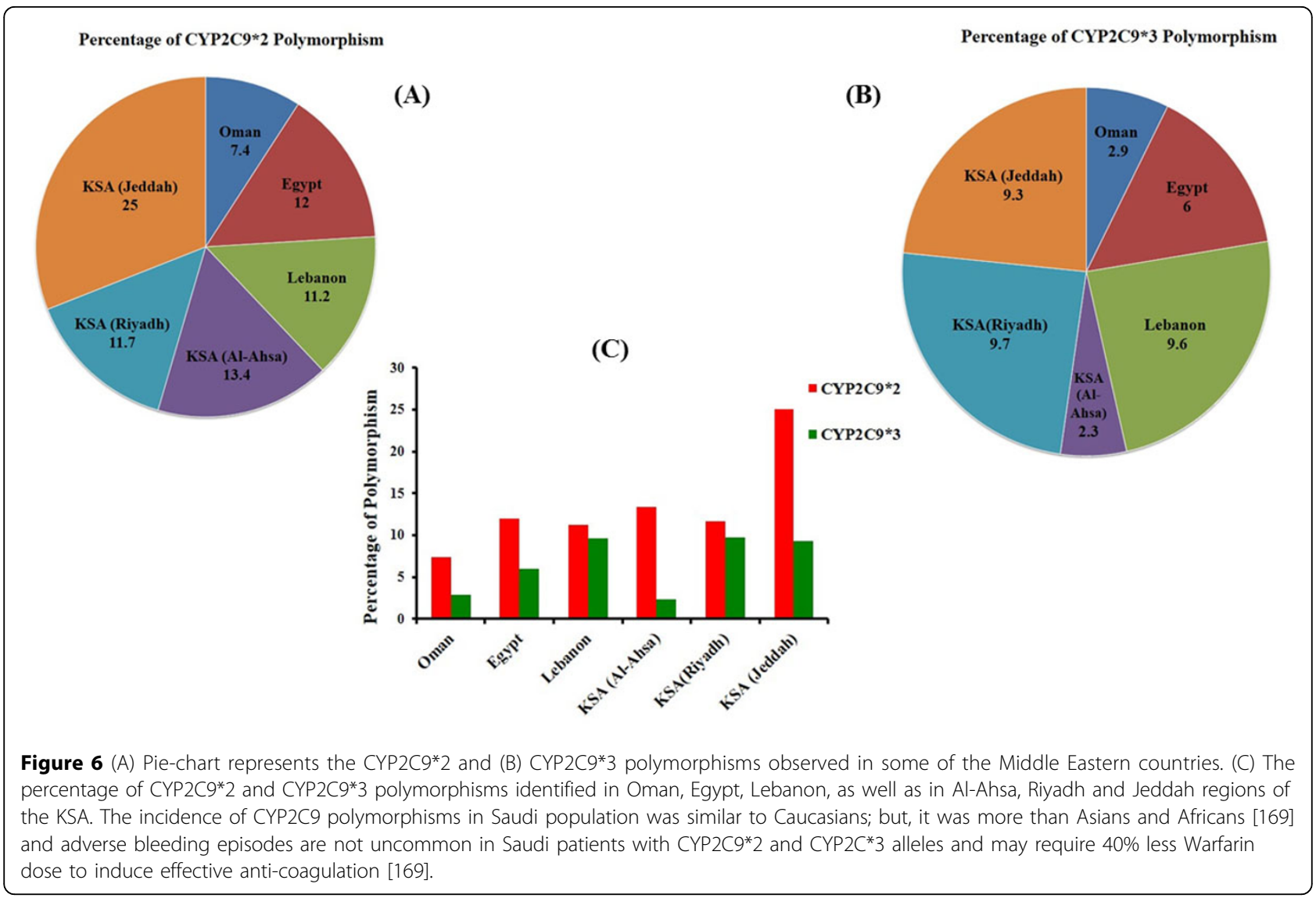

options for patients to minimize the risk of ADRs and suboptimal dose response [152]. It was estimated that about $25 \%$ of all prescribed drugs in the USA contain PGx labelling [136,153], for example, the anti-coagulant Warfarin with PGx indications of CYP2C9 genotype specific dosing $[136,154]$. The FDA has published a table of PGx biomarkers in drug labelling of about 135 therapeutically relevant drugs in the market $[26,155]$.

Though the advancing technologies in genomics and bioinformatics rapidly steer PGx towards personalized therapy for patients in clinics, PGx tests are currently limited to evaluate the safety and therapeutic efficacy of drugs for thromboembolic complications associated with atrial fibrillation and/or cardiac valve replacement, human immunodeficiency virus, chronic myeloid leukaemia and gastrointestinal stromal tumours, ALL, colon, breast and lung cancers [156].

At present, the key challenges of personalized medicine include; achieving the goal of $\$ 1000$ genome [157], increasing the speed of genome or exome sequencing by yet to be developed technologies [156], and making these platforms user friendly. Moreover, establishing dynamic PGx tools and databases [158-160], training physicians to apply PGx results to formulate preventive and personalized healthcare [161], and establishing privacy rules will be required to further the translational science $[122,156]$. At CEGMR, we are currently in the process of establishing custom-built PGx tools and databases as well as evaluating the PGx and toxicogenomics of several drugs used for the treatment of diseases afflicting Saudi population. Last, but perhaps most important, will be to, establish proper allele frequencies in populations from Saudi regions and others from across the globe $[123,156]$.

\section{Discussion and summary}

All of the investments in equipment in genomics infrastructure, and informatics at CEGMR aid in generating fundamental knowledge to facilitate effective decision making for individuals and families. Our primary objective is to generate the highest quality genomic data from patients and relevant family and population controls to enable opportunity for point-of-care, as well as iterative decision making based on the comparative medical data available. The advantage in the Saudi system is centralized medical care and shared experiences in families, which will also enable genome-based discoveries and treatments among families, physicians, and researchers [162].

We also recognize the importance of thoughtful deliberation on issues of societal awareness about consanguinity, 
infertility, and stigma associated with some genetic disorders and malformations. Therefore, the authority has launched several education and outreach programs in hospitals and schools [163]. CEGMR will continue to launch proactive communication plans with stakeholders such as government, media, children with disabilities, charitable associations, and other society representatives. Coupled with research, will also be newer ethical consenting processes that are particularly conscience of the vast array of genetic findings (and their implications) that arise from genome scanning [164]. Much of the data will be amenable to confidentiality, protection and control using an informatics-based approach $[165,166]$. However, there remains an urgent need in Saudi Arabia for up to date policies that comply with international standards, which implement strict control and protection of privacy and public release of bio-specimens and data [166-168]. CEGMR will also continue to develop and implement new algorithms and databases enabling iterative dynamic interpretations of data in personalized health decision making [169-171].

Other considerations relevant to translational medicine in the Saudi system include making reproductive health and ART more accessible and affordable for the average Saudi citizen so this approach can further ease the current staggering impact congenital malformations and genetic disease are having on the health care system [41]. We believe that there is a need for a strategic plan to recommend the PGD for patients with hereditary genetic disorders and receiving IVF services in the Kingdom. There also needs to be proactive and clear policies on the use of the human Embryonic Stem Cells (hESCs) and these should be easily accessed by all who are interested in the human stem cells research.

\section{Disclosures}

The authors disclose no competing financial interests.

\section{List of abbreviations}

ADRs: Adverse Drug Reactions; ALL: Acute Lymphoblastic Leukaemia; APS Advanced Premarital Screening; ART: Assisted Reproductive Technologies; ASR: Average Standardized Rates; CDH1: Cadherin-1; CEGMR: Centre of Excellence in Genomic Medicine Research; CGH: Comparative Genomic Hybridization; CHD: Congenital Heart Defects; CIMP: CpG Island Methylator Phenotype; CIPM: Centre of Innovation for Personalized Medicine; CNS: Central Nervous System; CTGA: Catalogue of Transmission Genetics in Arabs; DMD: Duchene Muscular Dystrophy; DME: Drug Metabolizing Enzyme; EMs: Extensive Metabolizer; eSET: elective Single Embryo Transfer; ESR1: Estrogen Receptor-1; FDA: Food and Drug Administration; G1: Gastrointestinal; GCC: Gulf Cooperation Council; G6PD: Glucose-6-phosphate dehydrogenase; GWAS: Genome Wide Association Studies; HESCs: human Embryonic Stem Cells; IARC: International Agency for Research on Cancer; IMs: Intermediate Metabolizers; IVF: in vitro fertilization; KACST: King Abdullah City for Science and Technology; KAU: King Abdulaziz University; KFSH \& RC: King Faisal Specialist Hospital \& Research Centre; KSA: Kingdom of Saudi Arabia; MOH: Ministry Of Health; ND: Not Determined; NGS: Next Generation Sequencing; NHL: Non-Hodgkin's Lymphoma; NSAIDs: Non-Steroidal Anti-Inflammatory Drugs; PGD: Pre-implantation Genetic Diagnosis; PGt: Pharmacogenetics; PGX: Pharmacogenomics; PMs: Poor Metabolizers; SADRs: Serious Adverse Drug
Reactions; SCD: Sickle Cell Disease; SHGP: Saudi Human Genome Program; SNPs: Single Nucleotide Polymorphisms; T2DM: Type 2 Diabetes Mellitus; UMs: Ultra-rapid Metabolizers

\section{Authors' contribution}

M.A.E., S.W.S., M.A. and M.Q. developed the topic and designed the review. All authors contributed to writing up the review. M.A.E. led the teamwork. M.A., H.S., P.P. and M.A.E. designed and made the figures. S.W. S. and M.A.E. edited the manuscript.

\section{Acknowledgement}

We would like to thank KACST for funding and supporting research in Saudi Arabia from which many results are reported in this review. MAE is funded by KACST Project Codes: 13-BIO789-03, 13-BIO669-03 and 13-CIPM-1. PP is funded by KACST Strategic Project Codes: 12-BIO2719-03 and 12-BIO2267-03. FA is funded by KACST Strategic Project Codes: 09-BIO-693-03.

\section{Declarations}

Publication charges for this article were funded by the Center of Excellence in Genomic Medicine Research (CEGMR), King Abdulaziz University, Jeddah, 21589, Kingdom of Saudi Arabia.

This article has been published as part of BMC Medical Genomics Volume 8 Supplement 1, 2015: Selected articles from the 2nd International Genomic Medical Conference (IGMC 2013): Medical Genomics. The full contents of the supplement are available online at http://www.biomedcentral.com/ bmcmedgenomics/supplements/8/S1

\section{Authors' details}

${ }^{1}$ Centre of Excellence in Genomic Medicine Research (CEGMR), King Abdulaziz University, P.O. Box: 80216 Jeddah 21589, KSA. ${ }^{2}$ KACST Technology Innovation Centre in Personalized Medicine at King Abdulaziz University (CIPM), P.O. Box: 80216 Jeddah 21589, KSA. ${ }^{3}$ School of Biological Sciences, University of East Anglia, Norwich, Norfolk, NR4 7TJ, UK. ${ }^{4}$ Zoology Department, Faculty of Science, Minia University, Minia, P.O. Box 61519, Egypt. ${ }^{5}$ The Centre for Applied Genomics and Program in Genetics and Genome Biology, the Hospital for Sick Children, Toronto, Ontario, Canada. ${ }^{6}$ McLaughlin Centre and Department of Molecular Genetics, University of Toronto, Toronto, Ontario, Canada.

Published: 15 January 2015

\section{References}

1. Tadmouri GO, Al Ali MT, Al-Haj Ali S, Al Khaja N: CTGA: the database for genetic disorders in Arab populations. Nucleic acids research 2006, 34(Database issue):D602-606.

2. Qatar Biobank for Medical Research. [http://www.qatarbiobank.org.qa/]

3. Saudi Human Genome Program. [http://rc.kfshrc.edu.sa/sgp/].

4. Tadmouri GO, Nair P, Obeid T, Al Ali MT, Al Khaja N, Hamamy HA: Consanguinity and reproductive health among Arabs. Reproductive health 2009, 6:17

5. Memish ZA, Saeedi MY: Six-year outcome of the national premarital screening and genetic counseling program for sickle cell disease and beta-thalassemia in Saudi Arabia. Annals of Saudi medicine 2011, 31(3):229-235.

6. Ng SW, Zaghloul S, Ali HI, Harrison G, Popkin BM: The prevalence and trends of overweight, obesity and nutrition-related non-communicable diseases in the Arabian Gulf States. Obesity reviews : an official journal of the International Association for the Study of Obesity 2011, 12(1):1-13.

7. Fortina P, Khaja NA, Ali MT, Hamzeh AR, Nair P, Innocenti F, Patrinos GP, Kricka LJ: Genomics into healthcare: the 5th pan arab human genetics conference and 2013 golden helix symposium. Human mutation 2014, 35(5):637-640

8. Scherer SW: Genomics is the medium for 21st century biology. Genome / National Research Council Canada $=$ Genome / Conseil national de recherches Canada 2012, 55(10):v.

9. Sheridan E, Wright J, Small N, Corry PC, Oddie S, Whibley C, Petherick ES, Malik T, Pawson N, McKinney PA, et al: Risk factors for congenital anomaly in a multiethnic birth cohort: an analysis of the Born in Bradford study. Lancet 2013, 382(9901):1350-1359.

10. Fida NM, Al-Aama J, Nichols W, Nichols W, Alqahtani M: A prospective study of congenital malformations among live born neonates at a 
University Hospital in Western Saudi Arabia. Saudi medical journal 2007, 28(9):1367-1373.

11. Becker SM, Al Halees Z, Molina C, Paterson RM: Consanguinity and congenital heart disease in Saudi Arabia. American journal of medical genetics 2001, 99(1):8-13.

12. El Mouzan Ml, Al Salloum AA, Al Herbish AS, Qurachi MM, Al Omar AA: Consanguinity and major genetic disorders in Saudi children: a community-based cross-sectional study. Annals of Saudi medicine 2008, 28(3):169-173.

13. Al Bu Ali WH, Balaha MH, Al Moghannum MS, Hashim I: Risk factors and birth prevalence of birth defects and inborn errors of metabolism in Al Ahsa, Saudi Arabia. The Pan African medical journal 2011, 8:14.

14. Shoukri MM, Donner A, Dessouky NA, Subhani S, Al-Joufan M, Al-Omrani A, Al-Mohanna F, Al Halees ZY: Estimation of modified concordance ratio in sib-pairs: effect of consanguinity on the risk of congenital heart diseases. The international journal of biostatistics 2010, 6(1), Article 3 .

15. Al-Mesned A, Al Akhfash AA, Sayed M: Incidence of severe congenital heart disease at the province of Al-Qassim, Saudi Arabia. Congenital heart disease 2012, 7(3):277-282.

16. Mitri W, Sandridge AL, Subhani S, Greer W: Design and development of an Internet registry for congenital heart defects. Teratology 2002, 65(2):78-87.

17. el-Hazmi MA, al-Swailem AR, Warsy AS, al-Swailem AM, Sulaimani $R$, alMeshari AA: Consanguinity among the Saudi Arabian population. Journal of medical genetics 1995, 32(8):623-626.

18. Greer W, Sandridge AL, Al-Menieir M, Al Rowais A: Geographical distribution of congenital heart defects in Saudi Arabia. Annals of Saudi medicine 2005, 25(1):63-69.

19. al-Jurayyan NA, Shaheen FI, al-Nuaim AA, el-Desouki MI, Faiz A, al Herbish AS, Bakr AM, al-Swailem AA, al Mazrou YY: Congenital hypothyroidism: increased incidence in Najran province, Saudi Arabia. Journal of tropical pediatrics 1996, 42(6):348-351.

20. Al-Jurayyan NA, Al-Herbish AS, El-Desouki Ml, Al-Nuaim AA, Abo-Bakr AM, Al-Husain MA: Congenital anomalies in infants with congenital hypothyroidism: is it a coincidental or an associated finding? Human heredity 1997, 47(1):33-37.

21. Al-Jurayyan NA, Al-Nuaim AA, Redha MA, El-Desouki Ml, Al Herbish AS, Abo Bakr AM, Al Swailem AA, Al Mazrou YY, Al Deress A: Neonatal screening for congenital hypothyroidism in Riyadh: Analysis of six year's experience. Annals of Saudi medicine 1996, 16(1):20-23.

22. Asindi AA, Al-Daama SA, Zayed MS, Fatinni YA: Congenital malformation of the gastrointestinal tract in Aseer region, Saudi Arabia. Saudi medical journal 2002, 23(9):1078-1082.

23. Asindi A, Al-Shehri A: Neural tube defects in the Asir Region of Saudi Arabia. Annals of Saudi medicine 2001, 21(1-2):26-29.

24. El-Awad Mel H, Sivasankaran S: Neural tube defects in Southwestern region of Saudi Arabia. Annals of Saudi medicine 1992, 12(5):449-452.

25. Bassuni W, Abbag F, Asindi A, Al Barki A, Al Binali AM: Neonatal deaths in the Asir Region of Saudi Arabia: Experience in a Referral Neonatal Intesive Care Unit. Annals of Saudi medicine 1997, 17(5):522-526.

26. Alqurashi M, El Mouzan M, Al Herbish A, Al Salloum A, Al Omer A: Symptomatic congenital heart disease in the Saudi Children and Adolescents Project. Annals of Saudi medicine 2007, 27(6):442-444.

27. Hakami WS, Majeed-Saidan MA: The incidence and spectrum of central nervous system malformations in newborns over a decade (2001-2010) in the Central Region of Saudi Arabia. Saudi medical journal 2011, 32(11):1137-1142.

28. Murshid WR: Spina bifida in Saudi Arabia: is consanguinity among the parents a risk factor? Pediatr Neurosurg 2000, 32(1):10-12.

29. Miao CY, Zuberbuhler JS, Zuberbuhler JR: Prevalence of congenital cardiac anomalies at high altitude. Journal of the American College of Cardiology 1988, 12(1):224-228.

30. Herrera R, Li Lora JA, Ingalls TH, Marticorena E: [Congenital malformations in the newborns at high altitude]. Archivos de biologia andina 1977, 7(2):94-101.

31. Castilla EE, Lopez-Camelo JS, Campana H: Altitude as a risk factor for congenital anomalies. American journal of medical genetics 1999, 86(1):9-14.

32. Adnan Amin Alsulaimani AKA: Prevalence of congenital anomalies at high altitude area in saudi arabia. Saudi medical journal 2010, 1(3):44-51.

33. Al-Othaimeen Al, Al-Nozha M, Osman AK: Obesity: an emerging problem in Saudi Arabia. Analysis of data from the National Nutrition Survey.
Eastern Mediterranean health journal $=$ La revue de sante de la Mediterranee orientale = al-Majallah al-sihhiyah li-shara al-mutawassit 2007, 13(2):441-448.

34. Balaha MH, Ali WH, Al Aswad LH, Al Moghannum MS, Hashim I: Maternal obesity predict isolated birth defects in live births in Eastern Province of Saudi Arabia. The journal of maternal-fetal \& neonatal medicine : the official journal of the European Association of Perinatal Medicine, the Federation of Asia and Oceania Perinatal Societies, the International Society of Perinatal Obstet 2012, 25(7):924-929.

35. Eyaid W, Al-Tassan RS, Al-Nouri DM: Intracranial calcifications, microcephaly, and seizure. If not congenital infection, what could it be? In Neurosciences. Volume 17. Riyadh, Saudi Arabia; 2012:(3):248-252.

36. El-Hazmi MA: The natural history and the national pre-marital screening program in Saudi Arabia. Saudi medical journal 2004, 25(11):1549-1554.

37. Cannistraci CV, Ogorevc J, Zorc M, Ravasi T, Dovc P, Kunej T: Pivotal role of the muscle-contraction pathway in cryptorchidism and evidence for genomic connections with cardiomyopathy pathways in RASopathies. BMC medical genomics 2013, 6:5.

38. Al-Qattan MM, Al-Thunayan A, Alabdulkareem I, Al Balwi M: Liebenberg syndrome is caused by a deletion upstream to the PITX1 gene resulting in transformation of the upper limbs to reflect lower limb characteristics. Gene 2013, 524(1):65-71.

39. Al-Odaib AN, Abu-Amero KK, Ozand PT, Al-Hellani AM: A new era for preventive genetic programs in the Arabian Peninsula. Saudi medical journal 2003, 24(11):1168-1175.

40. Al-Odaib A: Saudi Newborn Screening (NBS) Program for Metabolic Diseases. Princ Salamn Centre for Disability Research; 2003 [http://www. pscdr.org.sa/en/research/projects/Pages/SaudiNewbornScreening[NBS] ProgramforMetabolicDiseases.aspx].

41. Zegers-Hochschild F, Adamson GD, de Mouzon J, Ishihara O, Mansour R, Nygren K, Sullivan E, van der Poel S: The International Committee for Monitoring Assisted Reproductive Technology (ICMART) and the World Health Organization (WHO) Revised Glossary on ART Terminology, 2009. Hum Reprod 2009, 24(11):2683-2687.

42. Mundi I: Saudi Arabia Demographics Profile. 2013 [http:// wwwindexmundicom/saudi_arabia/demographics_profilehtml].

43. Boivin J, Bunting L, Collins JA, Nygren KG: International estimates of infertility prevalence and treatment-seeking: potential need and demand for infertility medical care. In Human reproduction. Volume 22. Oxford, England; 2007:(6):1506-1512.

44. WHO: Health topics: Infertility. World Health Organization 2013 [http:// www.who.int/topics/infertility/en/].

45. Dyer SJ: International estimates on infertility prevalence and treatment seeking: potential need and demand for medical care. Hum Reprod 2009, 24(9):2379-2380, author reply 2380-2373.

46. Buhling KJ, Grajecki D: The effect of micronutrient supplements on female fertility. Current opinion in obstetrics \& gynecology 2013, 25(3):173-180.

47. Mascarenhas MN, Flaxman SR, Boerma T, Vanderpoel S, Stevens GA: National, regional, and global trends in infertility prevalence since 1990 : a systematic analysis of 277 health surveys. PLoS medicine 2012, 9(12): e1001356.

48. Liu J, Wang W, Sun X, Liu L, Jin H, Li M, Witz C, Williams D, Griffith J, Skorupski J, et al: DNA microarray reveals that high proportions of human blastocysts from women of advanced maternal age are aneuploid and mosaic. Biology of reproduction 2012, 87(6):148.

49. Duncan FE, Hornick JE, Lampson MA, Schultz RM, Shea LD, Woodruff TK: Chromosome cohesion decreases in human eggs with advanced maternal age. Aging cell 2012, 11(6):1121-1124.

50. Desai N, Sabanegh E Jr., Kim T, Agarwal A: Free radical theory of aging: implications in male infertility. Urology 2010, 75(1):14-19.

51. Okun N, Sierra S, Wilson RD, Audibert F, Brock JA, Campagnolo C, Carroll J, Cartier L, Chitayat D, Gagnon A, et al: Pregnancy outcomes after assisted human reproduction. Journal of obstetrics and gynaecology Canada : JOGC = Journal d'obstetrique et gynecologie du Canada : JOGC 2014, 36(1):64-83.

52. Gerris J: Single-embryo transfer versus multiple-embryo transfer. Reproductive biomedicine online 2009, 18(Suppl 2):63-70.

53. Esteves SC, Miyaoka R, Agarwal A: Sperm retrieval techniques for assisted reproduction. International braz j urol : official journal of the Brazilian Society of Urology 2011, 37(5):570-583.

54. Agarwal A, Bragais FM, Sabanegh E: Assessing sperm function. The Urologic clinics of North America 2008, 35(2):157-171, vii. 
55. Mehri S, Levi Setti PE, Greco K, Sakkas D, Martinez G, Patrizio P: Correlation between follicular diameters and flushing versus no flushing on oocyte maturity, fertilization rate and embryo quality. Journal of assisted reproduction and genetics 2014, 31(1):73-77.

56. Assidi M, Sirard M-A: Cumulus Cell Gene Expression as a Marker of Oocyte Quality. In Oogenesis. London: Springer;Coticchio G, Albertini DF, De Santis L 2013:231-252.

57. Forman EJ, Tao X, Ferry KM, Taylor D, Treff NR, Scott RT Jr.: Single embryo transfer with comprehensive chromosome screening results in improved ongoing pregnancy rates and decreased miscarriage rates. Hum Reprod 2012, 27(4):1217-1222.

58. Straughen JK, Salihu HM, Keith L, Petrozzino J, Jones C: Obligatory versus elective single embryo transfer in in vitro fertilization. A populationbased analysis of data from the U.K. Human Fertilisation and Embryology Authority. The Journal of reproductive medicine 2013, 58(34):95-100.

59. Hodes-Wertz B, Grifo J, Ghadir S, Kaplan B, Laskin CA, Glassner M, Munne S: Idiopathic recurrent miscarriage is caused mostly by aneuploid embryos. Fertility and sterility 2012, 98(3):675-680.

60. Kochhar PK, Ghosh P: Reproductive outcome of couples with recurrent miscarriage and balanced chromosomal abnormalities. The journal of obstetrics and gynaecology research 2013, 39(1):113-120.

61. Lo Giacco D, Chianese C, Sanchez-Curbelo J, Bassas L, Ruiz P, Rajmil O, Sarquella J, Vives A, Ruiz-Castane E, Oliva R, et al: Clinical relevance of $Y$ linked CNV screening in male infertility: new insights based on the 8year experience of a diagnostic genetic laboratory. European journal of human genetics: EJHG 2013.

62. Ibrahim NK, Bashawri J, Al Bar H, Al Ahmadi J, Al Bar A, Qadi M, Milaat W, Feda H: Premarital Screening and Genetic Counseling program: knowledge, attitude, and satisfaction of attendees of governmental outpatient clinics in Jeddah. Journal of infection and public health 2013, 6(1):41-54

63. Adashi EY, Barri PN, Berkowitz R, Braude P, Bryan E, Carr J, Cohen J, Collins J, Devroey P, Frydman R, et al: Infertility therapy-associated multiple pregnancies (births): an ongoing epidemic. Reproductive biomedicine online 2003, 7(5):515-542.

64. Yuen RK, Merkoulovitch A, Macdonald JR, Vlasschaert M, Lo K, Grober E, Marshall CR, Jarvi KA, Kolomietz E, Scherer SW: Development of a highresolution Y-chromosome microarray for improved male infertility diagnosis. Fertility and sterility 2014.

65. Nepomnyashchaya YN, Artemov AV, Roumiantsev SA, Roumyantsev AG, Zhavoronkov A: Non-invasive prenatal diagnostics of aneuploidy using next-generation DNA sequencing technologies, and clinical considerations. Clinical chemistry and laboratory medicine : CCLM / FESCC 2013, 51(6):1141-1154.

66. Colls P, Escudero T, Fischer J, Cekleniak NA, Ben-Ozer S, Meyer B, Damien M, Grifo JA, Hershlag A, Munne S: Validation of array comparative genome hybridization for diagnosis of translocations in preimplantation human embryos. Reproductive biomedicine online 2012, 24(6):621-629.

67. Al-Hamdan N, Ravichandran K, Al-Sayyad J, Al-Lawati J, Khazal Z, AlKhateeb F, Abdulwahab A, Al-Asfour A: Incidence of cancer in Gulf Cooperation Council countries, 1998-2001. Eastern Mediterranean health journal $=$ La revue de sante de la Mediterranee orientale $=$ al-Majallah alsihhiyah li-shara al-mutawassit 2009, 15(3):600-611.

68. 10-Year Cancer Incidence Among Nationals of the GCC States 19982007. [http://www.moh.gov.bh/pdf/publications/GCC\%20Cancer\% 20Incidence\%202011.pdf].

69. World Health Organization, Regional Office for the Eastern Mediterranean, Cancer registration in the Region. [http://www.emro.who.int/ noncommunicable-diseases/information-resources/cancer-registration.html].

70. Cancer Incidence Report in Saudi Arabia 2009. [http://scr.clearvision.com.sa/]

71. GLOBOCAN 2012 v1.0, Cancer Incidence and Mortality Worldwide: IARC CancerBase No. 11. [http://globocan.iarc.fr].

72. SEER Cancer Statistics Review, 1975-2010. In SEER web site. National Cancer Institute. Bethesda, MD;Howlader N NA, Krapcho M, Garshell J, Neyman N, Altekruse SF, Kosary CL, Yu M, Ruhl J, Tatalovich Z, Cho H, Mariotto A, Lewis DR, Chen HS, Feuer EJ, Cronin KA 2013:, November 2012 SEER data submission.

73. Al-Zahrani AS, Ravichandran K: Epidemiology of thyroid cancer: a review with special reference to Gulf Cooperation Council (GCC) states. The Gulf journal of oncology 2007, , 2: 17-28.
74. Hussain F, lqbal S, Mehmood A, Bazarbashi S, ElHassan T, Chaudhri N: Incidence of thyroid cancer in the Kingdom of Saudi Arabia, 2000-2010. Hematology/oncology and stem cell therapy 2013, 6(2):58-64.

75. Alghamidi IG, Hussain II, Alghamdi MS, El-Sheemy MA: The incidence rate of prostate cancer in Saudi Arabia: an observational descriptive epidemiological analysis of data from the Saudi Cancer Registry 20012008. Hematology/oncology and stem cell therapy 2013.

76. Elkum N, Dermime S, Ajarim D, Al-Zahrani A, Alsayed A, Tulbah A, Al Malik O, Alshabanah M, Ezzat A, Al-Tweigeri T: Being 40 or younger is an independent risk factor for relapse in operable breast cancer patients: the Saudi Arabia experience. BMC cancer 2007, 7:222.

77. Chouchane L, Boussen H, Sastry KS: Breast cancer in Arab populations: molecular characteristics and disease management implications. The lancet oncology 2013, 14(10):e417-424

78. Alanazi M, Pathan AA, Arifeen Z, Shaik JP, Alabdulkarim HA, Semlali A, Bazzi MD, Parine NR: Association between PARP-1 V762A Polymorphism and Breast Cancer Susceptibility in Saudi Population. PloS one 2013, 8(12):e85541.

79. Siraj AK, Al-Rasheed M, Ibrahim M, Siddiqui K, Al-Dayel F, Al-Sanea O, Uddin S, Al-Kuraya K: RAD52 polymorphisms contribute to the development of papillary thyroid cancer susceptibility in Middle Eastern population. Journal of endocrinological investigation 2008, 31(10):893-899.

80. Siraj AK, Ibrahim M, Al-Rasheed M, Abubaker J, Bu R, Siddiqui SU, Al-Dayel F, Al-Sanea O, Al-Nuaim A, Uddin S, et al: Polymorphisms of selected xenobiotic genes contribute to the development of papillary thyroid cancer susceptibility in Middle Eastern population. BMC medical genetics 2008, 9:61.

81. Al-Qasem A, Toulimat M, Tulbah A, Elkum N, Al-Tweigeri T, Aboussekhra A: The p53 codon 72 polymorphism is associated with risk and early onset of breast cancer among Saudi women. Oncology letters 2012, 3(4):875-878.

82. Al-Sudairy R, Al-Nasser A, Alsultan A, Al Ahmari A, Abosoudah I, Al-Hayek R, Al-Harbi T, Al-Manjomi F, Al-Harbi M, Al-Ghamdi H, et al: Clinical characteristics and treatment outcome of childhood acute lymphoblastic leukemia in Saudi Arabia: a multi-institutional retrospective national collaborative study. Pediatric blood \& cancer 2014, 61(1):74-80.

83. Uddin S, Hussain A, Ahmed M, Belgaumi A, Al-Dayel F, Ajarim D, Bavi P, AlKuraya KS: S-phase kinase protein 2 is an attractive therapeutic target in a subset of diffuse large B-cell lymphoma. The Journal of pathology 2008, 216(4):483-494.

84. AlShemmari SH, Ameen RM, Sajnani KP: Extranodal lymphoma: a comparative study. In Hematology. Volume 13. Amsterdam, Netherlands; 2008:(3):163-169.

85. Temmim L, Baker $H$, Amanguno $H$, Madda JP, Sinowatz F: Clinicopathological features of extranodal lymphomas: Kuwait experience. Oncology 2004, 67(5-6):382-389.

86. Hussain AR, Uddin S, Ahmed M, Al-Dayel F, Bavi PP, Al-Kuraya KS: Phosphorylated IkappaBalpha predicts poor prognosis in activated B-cell lymphoma and its inhibition with thymoquinone induces apoptosis via ROS release. PloS one 2013, 8(3):e60540.

87. Hussain AR, Uddin S, Ahmed M, Bu R, Ahmed SO, Abubaker J, Sultana M, Ajarim D, Al-Dayel F, Bavi PP, et al: Prognostic significance of XIAP expression in DLBCL and effect of its inhibition on AKT signalling. The Journal of pathology 2010, 222(2):180-190.

88. Uddin S, Hussain AR, Ahmed M, Siddiqui K, Al-Dayel F, Bavi P, Al-Kuraya KS: Overexpression of FoxM1 offers a promising therapeutic target in diffuse large B-cell lymphoma. Haematologica 2012, 97(7):1092-1100.

89. Uddin S, Hussain AR, Ahmed M, Bu R, Ahmed SO, Ajarim D, Al-Dayel F, Bavi P, Al-Kuraya KS: Inhibition of fatty acid synthase suppresses c-Met receptor kinase and induces apoptosis in diffuse large B-cell lymphoma. Molecular cancer therapeutics 2010, 9(5):1244-1255.

90. Khan F, Ruterbusch JJ, Gomez SL, Schwartz K: Differences in the cancer burden among foreign-born and US-born Arab Americans living in metropolitan Detroit. Cancer causes \& control: CCC 2013, 24(11):1955-1961.

91. Siegel $R$, Naishadham D, Jemal A: Cancer statistics. CA: A Cancer J Clinicians 2013, 63(1):11-30.

92. Mehmood A, Te OB, Urcia JC, Khan A: Tumor Registry Annual Report. Kingdom of Saudi Arabia: King Faisal Specialist Hospital \& Research Center; 2011.

93. CancerStats. [http://www.cancerresearchuk.org/cancer-info/cancerstats/].

94. Al-Qutub ST, Al-Raddadi RM, Bin Sadiq BM, Sait W, Al-Gahmi A, AlAmoudi S: Potential breast cancer risk factors among Saudi women aged 
19-50 years in Jeddah: a case-control study. The Journal of the Egyptian Public Health Association 2013, 88(3):165-170.

95. PINK Indian Statistics. [http://www.breastcancerindia.net/bc/statistics/stati. $\mathrm{htm}]$.

96. El-Harith el HA, Abdel-Hadi MS, Steinmann D, Dork T: BRCA1 and BRCA2 mutations in breast cancer patients from Saudi Arabia. Saudi medical journal 2002, 23(6):700-704.

97. Hasan TN, Shafi G, Syed NA, Alsaif MA, Alsaif AA, Alshatwi AA: Lack of association of BRCA1 and BRCA2 variants with breast cancer in an ethnic population of Saudi Arabia, an emerging high-risk area. Asian Pacific journal of cancer prevention : APJCP 2013, 14(10):5671-5674

98. Hussein S, Merdad A, Al-Maghrabi J, Gari M, Al-Thubaiti F, Hussein I, Chaudhary A, Abuzenadah A, Tashkandi H, Al-Khayyat S, et al: Detection of rare single nucleotide variants affecting genes in the DNA repair pathways in hereditary breast cancer. BMC Genomics 2014, 15(Suppl 2):P20.

99. Saudi Human Genome Program. [http://rc.kfshrc.edu.sa/sgp/].

100. Jia Y, Lu Y, Wu K, Lin Q, Shen W, Zhu M, Huang S, Chen J: Does night work increase the risk of breast cancer? A systematic review and meta-analysis of epidemiological studies. Cancer epidemiology 2013, 37(3):197-206.

101. Kelleher FC, Rao A, Maguire A: Circadian molecular clocks and cancer. Cancer letters 2014, 342(1):9-18.

102. Zelinski EL, Deibel SH, McDonald RJ: The trouble with circadian clock dysfunction: Multiple deleterious effects on the brain and body. Neuroscience and biobehavioral reviews 2014, 40c:80-101.

103. Massart R, Freyburger M, Suderman M, Paquet J, El Helou J, BelangerNelson E, Rachalski A, Koumar OC, Carrier J, Szyf M, et al: The genomewide landscape of DNA methylation and hydroxymethylation in response to sleep deprivation impacts on synaptic plasticity genes. Translational psychiatry 2014, 4:e347.

104. Korkmaz A, Sanchez-Barcelo EJ, Tan DX, Reiter RJ: Role of melatonin in the epigenetic regulation of breast cancer. Breast cancer research and treatment 2009, 115(1):13-27.

105. Shylu Mathew AM, Jaudah Al-Maghrabi, Ashraf Dallol: Identification of frequent MTNR1B methylation in breast cancer following the application of high-throughput methylome analysis. BMC Genomics 2014, 15(Supplement 2)

106. Al-Daghri NM, Khan N, Alkharfy KM, Al-Attas OS, Alokail MS, Alfawaz HA, Alothman A, Vanhoutte PM: Selected dietary nutrients and the prevalence of metabolic syndrome in adult males and females in Saudi Arabia: a pilot study. Nutrients 2013, 5(11):4587-4604.

107. Buhmeida A, Dallol A, Merdad A, Al-Maghrabi J, Gari MA, Abu-Elmagd MM, Chaudhary AG, Abuzenadah AM, Nedjadi T, Ermiah E, et al: High fibroblast growth factor 19 (FGF19) expression predicts worse prognosis in invasive ductal carcinoma of breast. Tumour biology : the journal of the International Society for Oncodevelopmental Biology and Medicine 2013.

108. Dutra RL, de Carvalho MB, dos Santos M, Mercante AC, Gazito D, de Cicco R, Group G, Tajara EH, Louro ID, da Silva AMA: FGFR4 Profile as a Prognostic Marker in Squamous Cell Carcinoma of the Mouth and Oropharynx. PloS one 2012, 7(11).

109. Zaid TM, Yeung TL, Thompson MS, Leung CS, Harding T, Co NN, Schmandt RS, Kwan SY, Rodriguez-Aguay C, Lopez-Berestein G, et al: Identification of FGFR4 as a Potential Therapeutic Target for AdvancedStage High-Grade Serous Ovarian Cancer. Clinical cancer research : an official journal of the American Association for Cancer Research 2013, 19(4):809-820.

110. Luo $Y$, Yang C, Lu W, Xie R, Jin C, Huang P, Wang F, McKeehan WL: Metabolic Regulator ?Klotho Interacts with Fibroblast Growth Factor Receptor 4 (FGFR4) to Induce Apoptosis and Inhibit Tumor Cell Proliferation*. The Journal of Biological Chemistry 2010, 285(39):30069-30078

111. Poh W, Wong W, Ong H, Aung MO, Lim SG, Chua BT, Ho HK: Klotho-beta overexpression as a novel target for suppressing proliferation and fibroblast growth factor receptor-4 signaling in hepatocellular carcinoma. Molecular Cancer 2012, 11:14.

112. Dallol A, Al-Maghrabi J, Buhmeida A, Gari MA, Chaudhary AG, Schulten HJ, Abuzenadah AM, Al-Ahwal MS, Sibiany A, Al-Qahtani MH: Methylation of the polycomb group target genes is a possible biomarker for favorable prognosis in colorectal cancer. Cancer epidemiology, biomarkers \& prevention : a publication of the American Association for Cancer Research, cosponsored by the American Society of Preventive Oncology 2012, 21(11):2069-2075.
113. Buhmeida A, Merdad A, Al-Maghrabi J, Al-Thobaiti F, Ata M, Bugis A, Syrjanen K, Abuzenadah A, Chaudhary A, Gari M, et al: RASSF1A methylation is predictive of poor prognosis in female breast cancer in a background of overall low methylation frequency. Anticancer research 2011, 31(9):2975-2981.

114. Al-Moghrabi N, Al-Qasem AJ, Aboussekhra A: Methylation-related mutations in the BRCA1 promoter in peripheral blood cells from cancerfree women. International journal of oncology 2011, 39(1):129-135.

115. Shan J, Dsouza SP, Bakhru S, Al-Azwani EK, Ascierto ML, Sastry KS, Bedri S, Kizhakayil D, Aigha II, Malek J, et al: TNRC9 downregulates BRCA1 expression and promotes breast cancer aggressiveness. Cancer research 2013, 73(9):2840-2849.

116. Shan J, Mahfoudh W, Dsouza SP, Hassen E, Bouaouina N, Abdelhak S, Benhadjayed A, Memmi H, Mathew RA, Aigha II, et al: Genome-Wide Association Studies (GWAS) breast cancer susceptibility loci in Arabs: susceptibility and prognostic implications in Tunisians. Breast cancer research and treatment 2012, 135(3):715-724.

117. Alshatwi AA, Shafi G, Hasan TN, Syed NA, Al-Hazzani AA, Alsaif MA, Alsaif AA: Differential expression profile and genetic variants of microRNAs sequences in breast cancer patients. PloS one 2012, 7(2):e30049.

118. George GP, Gangwar R, Mandal RK, Sankhwar SN, Mittal RD: Genetic variation in microRNA genes and prostate cancer risk in North Indian population. Molecular biology reports 2011, 38(3):1609-1615.

119. Li P, Yan H, Zhang H, Yu L, Wang Z, Zhai Y, Xia X, Zhang J, Zhang Y, Ma F, et al: A Functional Polymorphism in MIR196A2 is Associated with Risk and Progression of Nasopharyngeal Carcinoma in the Chinese Population. Genetic testing and molecular biomarkers 2014, 18(3):149-155.

120. Hong YS, Kang HJ, Kwak JY, Park BL, You CH, Kim YM, Kim H: Association between microRNA196a2 rs11614913 genotypes and the risk of nonsmall cell lung cancer in Korean population. Journal of preventive medicine and public health = Yebang Uihakhoe chi 2011, 44(3):125-130.

121. Catucci I, Yang R, Verderio P, Pizzamiglio S, Heesen L, Hemminki K, Sutter C, Wappenschmidt B, Dick M, Arnold N, et al: Evaluation of SNPs in miR-146a, miR196a2 and miR-499 as low-penetrance alleles in German and Italian familial breast cancer cases. Human mutation 2010, 31(1):E1052-1057.

122. Issa AM: Ethical perspectives on pharmacogenomic profiling in the drug development process. Nature reviews Drug discovery 2002, 1(4):300-308.

123. Evans WE, McLeod HL: Pharmacogenomics-drug disposition, drug targets, and side effects. The New England journal of medicine 2003, 348(6):538-549.

124. Harrison $\mathrm{N}$ : Report on the pharmacogenomics and personalized medicine 2011 conference: part 1. Pharmacogenomics 2012, 13(2):141-145.

125. Wilke RA, Lin DW, Roden DM, Watkins PB, Flockhart D, Zineh I, Giacomini KM, Krauss RM: Identifying genetic risk factors for serious adverse drug reactions: current progress and challenges. Nature reviews Drug discovery 2007, 6(11):904-916.

126. Kalow W: Pharmacogenetics and pharmacogenomics: origin, status, and the hope for personalized medicine. The pharmacogenomics journal 2006, 6(3):162-165.

127. Pirmohamed M, Park BK: Genetic susceptibility to adverse drug reactions. Trends in pharmacological sciences 2001, 22(6):298-305.

128. Need AC, Motulsky AG, Goldstein DB: Priorities and standards in pharmacogenetic research. Nature genetics 2005, 37(7):671-681

129. Severino G, Del Zompo M: Adverse drug reactions: role of pharmacogenomics. Pharmacological research: the official journal of the Italian Pharmacological Society 2004, 49(4):363-373.

130. Giacomini KM, Krauss RM, Roden DM, Eichelbaum M, Hayden MR, Nakamura Y: When good drugs go bad. Nature 2007, 446(7139):975-977.

131. Nelson DR, Kamataki T, Waxman DJ, Guengerich FP, Estabrook RW, Feyereisen R, Gonzalez FJ, Coon MJ, Gunsalus IC, Gotoh O, et al: The P450 superfamily: update on new sequences, gene mapping, accession numbers, early trivial names of enzymes, and nomenclature. DNA and cell biology 1993, 12(1):1-51.

132. Nebert DW, Russell DW: Clinical importance of the cytochromes P450. Lancet 2002, 360(9340):1155-1162.

133. Nelson DR, Zeldin DC, Hoffman SM, Maltais $L$, Wain HM, Nebert DW: Comparison of cytochrome P450 (CYP) genes from the mouse and human genomes, including nomenclature recommendations for genes, pseudogenes and alternative-splice variants. Pharmacogenetics 2004, 14(1):1-18.

134. Danielson PB: The cytochrome P450 superfamily: biochemistry, evolution and drug metabolism in humans. Current drug metabolism 2002, 3(6):561-597. 
135. Fisher CD, Lickteig AJ, Augustine LM, Ranger-Moore J, Jackson JP, Ferguson SS, Cherrington NJ: Hepatic cytochrome P450 enzyme alterations in humans with progressive stages of nonalcoholic fatty liver disease. Drug metabolism and disposition: the biological fate of chemicals 2009, 37(10):2087-2094.

136. Bains RK: African variation at Cytochrome P450 genes: Evolutionary aspects and the implications for the treatment of infectious diseases. Evolution, medicine, and public health 2013, 1: 118-134.

137. Frye RF, Zgheib NK, Matzke GR, Chaves-Gnecco D, Rabinovitz M, Shaikh OS, Branch RA: Liver disease selectively modulates cytochrome P450mediated metabolism. Clinical pharmacology and therapeutics 2006, 80(3):235-245.

138. Fleeman N, Dundar Y, Dickson R, Jorgensen A, Pushpakom S, McLeod C, Pirmohamed M, Walley T: Cytochrome P450 testing for prescribing antipsychotics in adults with schizophrenia: systematic review and meta-analyses. The pharmacogenomics journal 2011, 11(1):1-14.

139. Cai WM, Chen B, Zhang WX: Frequency of CYP2D6*10 and *14 alleles and their influence on the metabolic activity of CYP2D6 in a healthy Chinese population. Clinical pharmacology and therapeutics 2007, 81(1):95-98.

140. Gasche Y, Daali Y, Fathi M, Chiappe A, Cottini S, Dayer P, Desmeules J: Codeine intoxication associated with ultrarapid CYP2D6 metabolism. The New England journal of medicine 2004, 351(27):2827-2831.

141. Kirchheiner J, Roots I, Goldammer M, Rosenkranz B, Brockmoller J: Effect of genetic polymorphisms in cytochrome p450 (CYP) 2C9 and CYP2C8 on the pharmacokinetics of oral antidiabetic drugs: clinical relevance. Clinical pharmacokinetics 2005, 44(12):1209-1225.

142. Holstein A, Beil W, Kovacs P: CYP2C metabolism of oral antidiabetic drugs-impact on pharmacokinetics, drug interactions and pharmacogenetic aspects. Expert opinion on drug metabolism \& toxicology 2012, 8(12):1549-1563.

143. Mirghani RA, Chowdhary G, Elghazali G: Distribution of the major cytochrome P450 (CYP) 2C9 genetic variants in a Saudi population. Basic \& clinical pharmacology \& toxicology 2011, 109(2):111-114.

144. Dai DP, Wang SH, Geng PW, Hu GX, Cai JP: In Vitro Assessment of 36 CYP2C9 Allelic Isoforms found in the Chinese Population on the Metabolism of Glimepiride. Basic \& clinical pharmacology \& toxicology 2013.

145. Pirmohamed M, Burnside G, Eriksson N, Jorgensen AL, Toh CH, Nicholson $T$, Kesteven $\mathrm{P}$, Christersson C, Wahlstrom B, Stafberg C, et al: A randomized trial of genotype-guided dosing of warfarin. The New England journal of medicine 2013, 369(24):2294-2303.

146. Zhang X, Li L, Ding X, Kaminsky LS: Identification of cytochrome P450 oxidoreductase gene variants that are significantly associated with the interindividual variations in warfarin maintenance dose. Drug metabolism and disposition: the biological fate of chemicals 2011, 39(8):1433-1439.

147. Tanira MO, Al-Mukhaini MK, Al-Hinai AT, Al Balushi KA, Ahmed IS: Frequency of CYP2C9 genotypes among Omani patients receiving warfarin and its correlation with warfarin dose. Community genetics 2007, 10(1):32-37.

148. Alzahrani AM, Ragia G, Hanieh H, Manolopoulos VG: Genotyping of CYP2C9 and VKORC1 in the Arabic population of Al-Ahsa, Saudi Arabia. BioMed research international 2013, 315980.

149. Hamdy SI, Hiratsuka M, Narahara K, El-Enany M, Moursi N, Ahmed MS, Mizugaki M: Allele and genotype frequencies of polymorphic cytochromes P450 (CYP2C9, CYP2C19, CYP2E1) and dihydropyrimidine dehydrogenase (DPYD) in the Egyptian population. British journal of clinical pharmacology 2002, 53(6):596-603.

150. Djaffar-Jureidini I, Chamseddine N, Keleshian S, Naoufal R, Zahed L, Hakime N: Pharmacogenetics of coumarin dosing: prevalence of CYP2C9 and VKORC1 polymorphisms in the Lebanese population. Genetic testing and molecular biomarkers 2011, 15(11):827-830.

151. Saour JN, Shereen AW, Saour BJ, Mammo LA: CYP2C9 polymorphism studies in the Saudi population. Saudi medical journal 2011, 32(4):347-352.

152. Heller T, Kirchheiner J, Armstrong WW, Luthe H, Tzvetkov M, Brockmoller J, Oellerich M: AmpliChip CYP450 GeneChip: a new gene chip that allows rapid and accurate CYP2D6 genotyping. Therapeutic drug monitoring 2006, 28(5):673-677.

153. Gardiner SJ, Begg EJ: Pharmacogenetics, drug-metabolizing enzymes, and clinical practice. Pharmacological reviews 2006, 58(3):521-590.

154. Seip RL, Duconge J, Ruano G: Implementing genotype-guided antithrombotic therapy. Future cardiology 2010, 6(3):409-424.

155. [http://www.fda.gov/drugs/scienceresearch/researchareas/ pharmacogenetics/ucm083378.htm]
156. Mohamed S, Syed BA: Commercial prospects for genomic sequencing technologies. Nature reviews Drug discovery 2013, 12(5):341-342.

157. DeFrancesco L: Life Technologies promises $\$ 1,000$ genome. Nature biotechnology 2012, 30(2):126.

158. Moore CB, Wallace JR, Frase AT, Pendergrass SA, Ritchie MD: BioBin: a bioinformatics tool for automating the binning of rare variants using publicly available biological knowledge. BMC medical genomics 2013, 6(Suppl 2):S6.

159. Moore CB, Wallace JR, Frase AT, Pendergrass SA, Ritchie MD: Using BioBin to explore rare variant population stratification. Pacific Symposium on Biocomputing Pacific Symposium on Biocomputing 2013, 332-343.

160. Gerasch A, Faber D, Kuntzer J, Niermann P, Kohlbacher O, Lenhof HP, Kaufmann M: BiNA: A Visual Analytics Tool for Biological Network Data. Plos one 2014, 9(2):e87397.

161. Frueh FW, Gurwitz D: From pharmacogenetics to personalized medicine: a vital need for educating health professionals and the community. Pharmacogenomics 2004, 5(5):571-579.

162. Buchanan JA, Carson AR, Chitayat D, Malkin D, Meyn MS, Ray PN, Shuman C, Weksberg R, Scherer SW: The cycle of genome-directed medicine. Genome medicine 2009, 1(2):16.

163. Ibrahim NK, Al-Bar H, Al-Fakeeh A, Al Ahmadi J, Qadi M, Al-Bar A, Milaat W: An educational program about premarital screening for unmarried female students in King Abdul-Aziz University, Jeddah. Journal of infection and public health 2011, 4(1):30-40.

164. Ali-Khan SE, Daar AS, Shuman C, Ray PN, Scherer SW: Whole genome scanning: resolving clinical diagnosis and management amidst complex data. Pediatric research 2009, 66(4):357-363.

165. McBride MS: Bioinformatics and Intellectual Property Protection. Berkeley technology law journal 2002, 17(4):1331-1334.

166. Manwar Hussain MR, Khan A, Ali Mohamoud HS: From Genes to Health Challenges and Opportunities. Frontiers in pediatrics 2014, 2:12.

167. D'Souza S: Gene meets machine: intellectual property issues in bioinformatics. Health Law Review 2004, 12(2):34-43.

168. Kesh S, Raghupathi W: Critical issues in bioinformatics and computing Perspectives in health information management / AHIMA, American Health Information Management Association 2004, 1:9.

169. Ogbogu U, Burningham S, Ollenberger A, Calder K, Du L, El Emam K, Hyde-Lay R, Isasi R, Joly $Y$, Kerr I, et al: Policy recommendations for addressing privacy challenges associated with cell-based research and interventions. BMC medical ethics 2014, 15:7

170. Vahakangas K: Research ethics in the post-genomic era. Environmental and Molecular Mutagenesis 2013, 54(7):599-610.

171. Bowdin S, Ray P, Cohn RD, Meyn MS: The Genome Clinic: A Multidisciplinary Approach to Assessing the Opportunities and Challenges of Integrating Genomic Analysis Into Clinical Care. Human mutation 2014

172. Niazi MA, al-Mazyad AS, al-Husain MA, al-Mofada SM, al-Zamil FA, Khashoggi TY, al-Eissa YA: Down's syndrome in Saudi Arabia: incidence and cytogenetics. Human heredity 1995, 45(2):65-69.

173. Refat MY, Al-Moghanem M, McDonald P, Reyes L: Major birth defects at King Fahd Hofuf Hospital: Prevalence, risk factors and outcome. Annals of Saudi medicine 1995, 15(4):339-343.

174. Almawazini AM, Al-Ghamdi AS: Congenital heart disease in south-west Saudi Arabia. Saudi medical journal 2011, 32(2):195-196.

175. Alabdulgader AA: Congenital heart disease in 740 subjects: epidemiological aspects. Annals of tropical paediatrics 2001, 21(2):111-118.

176. Nazer H, Riff E, Sakati N, Mathew R, Majeed-Saidan MA, Harfi H: Cystic fibrosis in Saudi Arabia. European journal of pediatrics 1989, 148(4):330-332

177. Banjar H: Morbidity and mortality data of cystic fibrosis patients. Saudi medical journal 2003, 24(7):730-735.

178. Zakzouk SM, Fadle KA, al Anazy FH: Familial hereditary progressive sensorineural hearing loss among Saudi population. International journal of pediatric otorhinolaryngology 1995, 32(3):247-255.

179. JAMAL TS, DAGHISTANI KJ, ZAKZOUK SS: Impact of Consanguinity on Childhood Hearing Impairment in a Saudi Population. J KAU: Med Sci 2002, 10:23-31.

180. Al-Qahtani MH, Baghlab I, Chaudhary AG, Abuzenadah AM, Bamanie A, Daghistani KJ, Safieh M, Fida L, Dallol A: Spectrum of GJB2 mutations in a cohort of nonsyndromic hearing loss cases from the Kingdom of Saudi Arabia. Genetic testing and molecular biomarkers 2010, 14(1):79-83. 
181. Tabbara KF, Badr IA: Changing pattern of childhood blindness in Saudi Arabia. The British journal of ophthalmology 1985, 69(4):312-315.

182. Tabbara KF, El-Sheikh HF, Shawaf SS: Pattern of childhood blindness at a referral center in Saudi Arabia. Annals of Saudi medicine 2005, 25(1):18-21.

183. Al-Nozha MM, Al-Maatouq MA, Al-Mazrou YY, Al-Harthi SS, Arafah MR, Khalil MZ, Khan NB, Al-Khadra A, Al-Marzouki K, Nouh MS, et al: Diabetes mellitus in Saudi Arabia. Saudi medical journal 2004, 25(11):1603-1610.

184. El-Hazmi MA, Warsy AS, Al-Swailem AR, Al-Swailem AM, Sulaimani R, AlMeshari AA: Diabetes mellitus and impaired glucose tolerance in Saudi Arabia. Annals of Saudi medicine 1996, 16(4):381-385.

185. Alhamdan NA, Almazrou YY, Alswaidi FM, Choudhry AJ: Premarital screening for thalassemia and sickle cell disease in Saudi Arabia. Genetics in medicine: official journal of the American College of Medical Genetics 2007, 9(6):372-377.

186. Akhtar MS, Qaw F, Borgio JF, Albuali W, Suliman A, Nasserullah Z, AlJarrash S, Al-Ali A: Spectrum of alpha-thalassemia mutations in transfusion-dependent beta-thalassemia patients from the Eastern Province of Saudi Arabia. Hemoglobin 2013, 37(1):65-73.

187. Memish ZA, Owaidah TM, Saeedi MY: Marked regional variations in the prevalence of sickle cell disease and beta-thalassemia in Saudi Arabia: findings from the premarital screening and genetic counseling program. Journal of epidemiology and global health 2011, 1(1):61-68.

188. Abuzenadah AM, Hussein IM, Damanhouri GA, FM AS, Gari MA, Chaudhary AG, Zaher GF, Al-Attas A, Al-Qahtani MH: Molecular basis of beta-thalassemia in the western province of Saudi Arabia: identification of rare beta-thalassemia mutations. Hemoglobin 2011, 35(4):346-357.

189. El Mouzan Ml, Al Awamy BH, Al Torki MT: Clinical features of sickle cell disease in eastern Saudi Arab children. The American journal of pediatric hematology/oncology 1990, 12(1):51-55.

190. Nasserullah Z, Alshammari A, Abbas MA, Abu-Khamseen Y, Qadri M, Jafer SA, Wabel MA: Regional experience with newborn screening for sickle cell disease, other hemoglobinopathies and G6PD deficiency. Annals of Saudi medicine 2003, 23(6):354-357.

191. Al-Qurashi MM, El-Mouzan MI, Al-Herbish AS, Al-Salloum AA, Al-Omar AA: The prevalence of sickle cell disease in Saudi children and adolescents. A community-based survey. Saudi medical journal 2008, 29(10):1480-1483.

192. El-Hazmi MA, Al-Hazmi AM, Warsy AS: Sickle cell disease in Middle East Arab countries. The Indian journal of medical research 2011, 134(5):597-610.

193. Muzaffer MA: Neonatal screening of glucose-6-phosphate dehydrogenase deficiency in Yanbu, Saudi Arabia. Journal of medical screening 2005, 12(4): 170-171.

194. Warsy AS, El-Hazmi MA: G6PD deficiency, distribution and variants in Saudi Arabia: an overview. Annals of Saudi medicine 2001, 21(3-4):174-177.

doi:10.1186/1755-8794-8-S1-S3

Cite this article as: Abu-Elmagd et al: Individualized medicine enabled by genomics in Saudi Arabia. BMC Medical Genomics 2015 8(Suppl 1):S3.

\section{Submit your next manuscript to BioMed Central and take full advantage of:}

- Convenient online submission

- Thorough peer review

- No space constraints or color figure charges

- Immediate publication on acceptance

- Inclusion in PubMed, CAS, Scopus and Google Scholar

- Research which is freely available for redistribution

Submit your manuscript at www.biomedcentral.com/submit 